\title{
Defining the mechanism by which IFN- $\beta$ dowregulates c-myc expression in human melanoma cells: pivotal role for human polynucleotide phosphorylase (hPNPase ${ }^{\text {old }-35}$ )
}

\author{
D Sarkar ${ }^{1}$, ES Park ${ }^{1}$ and PB Fisher, ${ }^{*, 1,2,3}$ \\ ${ }^{1}$ Department of Pathology, Herbert Irving Comprehensive Caner Center, \\ Columbia University Medical Center, College of Physicians and Surgeons, \\ New York, NY 10032, USA \\ 2 Department of Urology, Herbert Irving Comprehensive Caner Center, \\ Columbia University Medical Center, College of Physicians and Surgeons, \\ New York, NY 10032, USA \\ ${ }^{3}$ Department of Neurosurgery, Herbert Irving Comprehensive Cancer Center, \\ Columbia University Medical Center, College of Physicians and Surgeons, \\ New York, NY 10032, USA \\ * Corresponding author: PB Fisher, Department of Pathology, College of \\ Physicians \& Surgeons, Columbia University Medical Center, 630 West 168th \\ Street, BB-1501, New York, NY 10032, USA. Tel: + 1212305 3642; \\ Fax: + 1212305 8177; E-mail: pbf1@ columbia.edu
}

Received 22.7.05; revised 04.10.05; accepted 18.10.05; published online 13.1.06 Edited by V De Laurenzi

\begin{abstract}
Type I interferons (IFN- $\alpha$ I- $\beta$ ) are capable of suppressing c-myc mRNA expression by modulating post-transcriptional processing. However, the molecular mechanism of this phenomenon is poorly understood. We previously established that human polynucleotide phosphorylase (hPNPase ${ }^{\text {old }-35}$ ), a type I IFNinducible $3^{\prime}, 5^{\prime}$ exoribonuclease involved in mRNA degradation, induces $G_{1}$ cell cycle arrest and eventually apoptosis by specifically degrading c-myc mRNA. We now demonstrate a close association between IFN- $\beta$-induced $h P N P a s e^{\text {old-35 }}$ upregulation and c-myc downregulation in human melanoma cells. Employing stable melanoma cell clones expressing $h P N P a-$ $s e^{\text {old- }-35}$ small inhibitory RNA, we demonstrate that $h P N P a s e^{\text {old }-35}$ is a key molecule coupled with IFN- $\beta$-mediated downregulation of c-myc mRNA. Inhibition of hPNPase ${ }^{\text {old }-35}$ or overexpression of c-myc protects melanoma cells from IFN- $\beta$ mediated growth inhibition, emphasizing the importance of hPNPase ${ }^{\text {old }-35}$ upregulation and consequent c-myc downregulation in IFN- $\beta$-induced growth inhibition and apoptosis induction. In these contexts, targeted overexpression of hPNPase old- $-35^{-1}$ might be a novel therapeutic strategy for c-myc-overexpressing and IFN-resistant tumors, such as melanomas.
\end{abstract}

Cell Death and Differentiation (2006) 13, 1541-1553.

doi:10.1038/sj.cdd.4401829; published online 13 January 2006

Keywords: interferon; human polynucleotide phosphorylase (hPNPase $^{\text {old-35) }}$; c-myc; post-transcriptional processing

Abbreviations: GAS, gamma-activated sequence; $h P N P a s e^{\text {old-35, }}$ human polynucleotide phosphorylase; IFN, interferon; ISG, IFNstimulated genes; ISRE, interferon-stimulated regulatory elements;
MEZ, mezerein; OPS, overlapping pathway screening; PNPase, polynucleotide phosphorylase; siRNA, small inhibitory RNA; STAT, signal transducers and activators of transcription

\section{Introduction}

Interferons (IFNs) comprise a family of secreted cytokines displaying divergent activities, including protection against viral and bacterial infections, antitumor activity (both direct and immune system mediated) and stimulating or inhibiting differentiation depending on cellular context. ${ }^{1,2}$ Five classes of IFNs are currently recognized, including IFN- $\alpha$, IFN- $\beta$, IFN- $\gamma$, IFN- $\tau$ (bovine) and IFN- $\omega$, which display distinct biological activities, mode of induction and amino-acid sequence. ${ }^{1,2}$ Type I and II IFNs are classified based on interactions with their respective type I or II cell surface receptors. IFN- $\alpha$ (12 subtypes), IFN- $\beta$, IFN- $\tau$ and IFN- $\omega$ interact with type I IFN receptors and IFN- $\gamma$ binds and signals through type II IFN receptors. ${ }^{1,2}$ Although crosstalk between additional receptors and signaling pathways has been documented, biochemical approaches and genetic complementation studies using mutant cells demonstrate that the predominant signaling pathway that mediates activation of IFN-responsive genes involves JAK tyrosine kinases and signal transducers and activators of transcription (STATs). ${ }^{1,2}$ Binding of IFN- $\gamma$ with its cognate receptors results in phosphorylation (activation) of JAK1 and JAK2, which phosphorylates STAT1 that homodimerizes, translocates to the nucleus and binds to gammaactivated sequence (GAS) elements in the promoters of target genes to augment transcription. ${ }^{1,2}$ Type I IFN binding to cognate receptors results in sequential phosphorylation of Tyk2, JAK1, STAT1 and STAT2, and STAT1/STAT2 heterodimer translocates into the nucleus and interacts with IRF family transcription factor p48, thus generating the ISGF3 transcription factor complex that binds to interferon-stimulated regulatory elements (ISRE) in target promoters to drive transcription. ${ }^{1,2}$ Although the transcriptional regulation of IFNstimulated genes (ISGs) is well-understood, IFNs also downregulate the expression of many genes (http://bioinfo.cnio.es/ data/oncochip/) and the mechanism underlying this process is still unclear.

Human polynucleotide phosphorylase (hPNPase ${ }^{\text {old }-35}$ ) is a type I IFN-inducible early response gene. ${ }^{3-6}$ Biochemically, $h P N P a s e^{\text {old-35 }}$ is a $3^{\prime}, 5^{\prime}$ exoribonuclease catalyzing mRNA decay in a $3^{\prime}-5^{\prime}$ direction. ${ }^{3}$ Polynucleotide phosphorylase (PNPase) is an evolutionary conserved gene and the bacterial and plant enzymes have been cloned and extensively studied for decades. ${ }^{5}$ The human homolog was recently identified by our laboratory using a unique cloning strategy termed 'overlapping pathway screening' (OPS), in which a terminally differentiated human melanoma cDNA library 
was screened with cDNAs derived from senescent fibroblasts. $^{3}$ Terminal differentiation of human melanoma cells, induced by combined treatment with IFN- $\beta$ and the protein kinase $\mathrm{C}$ activator mezerein (MEZ), and cellular senescence share several common end points, one of which is irreversible growth arrest, and the premise underlying the OPS approach was to identify genes that are critical mediators of two significant physiological processes, namely terminal differentiation and senescence. ${ }^{7,8}$ In total, 75 ESTs, termed old 1-75, were identified by OPS and old-35, which was later recognized to be the human version of PNPase, was found to be consistently overexpressed during the terminal differentiation process in human melanoma cells and senescent human fibroblasts. ${ }^{3}$ While its expression was virtually undetectable in human melanoma cells under basal condition, hPNPase ${ }^{\text {old-35 }}$ was markedly induced within $6 \mathrm{~h}$ following treatment with IFN- $\beta$, highlighting a potentially prominent role in mediating IFN- $\beta$-induced molecular events. ${ }^{3}$

Of direct relevance to the present study, overexpression of hPNPase $e^{\text {old }-35}$ via an adenoviral vector (Ad.hPNPase ${ }^{\text {old-35 }}$ ) induces profound morphological, biochemical and gene expression changes that mimic the critical molecular and biochemical signatures of senescence as well as differentiation. ${ }^{6}$ hPNPase $e^{\text {old }-35}$ induces cell cycle arrest in the $\mathrm{G}_{1}$ phase with inhibition of DNA synthesis and telomerase activity, and activates the senescence-associated $\beta$-galactosidase en-

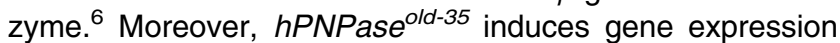
changes that are consistent with $\mathrm{G}_{1}$ cell cycle arrest, such as downregulation of $\mathrm{c}-\mathrm{myc}$, upregulation of $\mathrm{p} 27^{\mathrm{KIP}-1}$ and hypophosphorylation of $\mathrm{Rb}$. $^{6}$ We previously found that downregulation of c-myc plays a critical part in hPNPase old-35. induced growth inhibition, since overexpression of c-myc partially but significantly ablated this growth-inhibitory effect. $^{6,9}$ In vitro mRNA degradation assays revealed that, as an exoribonuclease, $h P N P a s e^{\text {old-35 }}$ directly and specifically degraded c-myc mRNA. ${ }^{6}$ hPNPase ${ }^{\text {old }-35}$ contains an Nterminal mitochondrial localization signal and its predominant site of localization is in the mitochondria.9,10 However, we have recently documented that in addition to mitochondrial localization a considerable amount of hPNPase old- 35 also resides in the cytoplasm, thus explaining the conundrum of how a mitochondrial exoribonuclease could degrade a cytoplasmic mRNA, like c-myc. ${ }^{10}$

The molecular mechanism of regulation of c-myc expression by IFN- $\beta$ still represents an enigma. It has been two decades since it was first demonstrated that IFN- $\beta$ downregulated $c-m y c$ expression and this downregulation involved modulation of post-transcriptional control of c-myc mRNA. ${ }^{11,12}$ However, the molecules and biochemical pathways involved in this post-transcriptional control remain to be elucidated. We previously demonstrated that $h P N P a e^{\text {old }-35}$ was induced very early upon IFN- $\beta$ treatment and $h P N P a s e^{\text {old-35 }}$ could specifically degrade c-myc mRNA. ${ }^{3,6,9}$ Based on these observations, we reasoned that $h P N P a s e^{\text {old-35 might }}$ be a key molecule regulating IFN- $\beta$-mediated downregulation of c-myc mRNA. Employing stable cell clones expressing hPNPase ${ }^{\text {old-35 }}$ small inhibitory RNA (siRNA) and c-myc, we now provide experimental validation of this hypothesis and establish for the first time the importance of upregulation of
hPNPase $e^{\text {old }-35}$ and subsequent downregulation of c-myc as direct mediators of IFN- $\beta$-induced growth inhibition and apoptosis induction in melanoma cells.

\section{Results}

\section{Regulation of $h P N P a s e^{o l d-35}$ and c-myc mRNA expression by IFN- $\beta$}

To define a potential correlation between the expression regulation of $h P N P a e^{\text {old }-35}$ and c-myc by IFN- $\beta, \mathrm{HO}-1$, WM35 and MeWo human melanoma cells and SV40 T/t Agimmortalized human melanocytes (FM-516-SV, henceforth indicated as FM-516) were treated with $1000 \mathrm{U} / \mathrm{ml}$ of IFN- $\beta$ for different times ranging from 12 to $48 \mathrm{~h}$ and the expression of

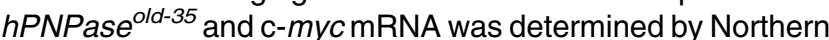
blot analysis (Figure 1a). Under basal condition, there was little to barely detectable $h P N P a s e^{\text {old }-35}$ mRNA expression in the different cell types. Upon IFN- $\beta$ treatment, a marked increase in $h P N P a s e^{\text {old-35 }}$ mRNA expression was detected $12 \mathrm{~h}$ post-treatment. In HO-1, WM-35 and FM-516 cells,

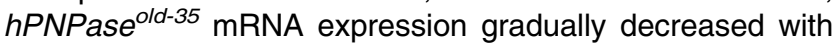
time and by $48 \mathrm{~h}$ post-IFN- $\beta$ treatment returned to the basal level. However, in MeWo cells, $h P N P a e^{\text {old- }-35}$ mRNA expression persisted even $48 \mathrm{~h}$ after IFN- $\beta$ treatment. While

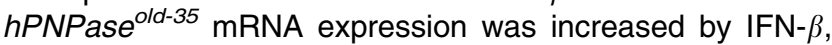
$c-m y c$ mRNA expression decreased with the same treatment and there was a temporal correlation in the expression regulation of these two mRNAs by IFN- $\beta$. A significant timedependent IFN- $\beta$-mediated decrease in c-myc mRNA expression was also evident in all four cell lines. In MeWo cells, with persistence of $h P N P a s e^{\text {old }-35}$ mRNA expression, c- myc mRNA expression disappeared completely at $48 \mathrm{~h}$ post-IFN- $\beta$ treatment.

The mRNA expression results were confirmed on a protein level by Western blot analysis (Figure 1b). Under basal condition, hPNPase ${ }^{\text {old-35 }}$ protein was undetectable in all four cell lines. With IFN- $\beta$ treatment, $h P N P a s e^{\text {old-35 }}$ protein expression was markedly induced and persisted even 2 days after treatment. With the exception of MeWo cells, the corresponding mRNA levels decreased at $48 \mathrm{~h}$ in HO-1, WM-35 and FM-516 cells. The Myc protein levels also showed a temporal decrease following IFN- $\beta$ treatment.

A direct correlation in IFN- $\beta$-induced dose-dependent changes in $h P N P a e^{\text {old-35 }}$ and Myc proteins was also evident. In HO-1 and WM-35 cells, hPNPase old-35 induction and Myc downregulation were detected with 100 and $1000 \mathrm{U} / \mathrm{ml}$ of IFN- $\beta$, but not with 1 or $10 \mathrm{U} / \mathrm{ml}$ (Figure $1 \mathrm{~b}$ ). In MeWo and FM- 516 cells, changes in protein levels could be detected with as little as 1 or $10 \mathrm{U} / \mathrm{ml}$ of IFN- $\beta$, respectively. In IFN- $\beta$-treated FM-516 cells, in addition to the Myc band, a faster migrating band was detected, which might represent a degradation product of the Myc protein. These findings confirm that the concentration of IFN- $\beta$ required to upregulate $h P N P a s e^{\text {old }-35}$ is also required to downregulate Myc protein, indicating a potential cooperative regulation in the expression of these two genes.

The regulation of expression of $h P N P a s e^{\text {old-35 }}$ and Myc by IFN- $\beta$ was confirmed in $2 \mathrm{fTGH}$ human fibrosarcoma cells and 
$\mathrm{HO}-1$

$\begin{array}{lllll}0 & 12 & 24 & 36 & 48\end{array}$

WM-35

$\begin{array}{lllll}0 & 12 & 24 & 36 & 48\end{array}$

MeWo

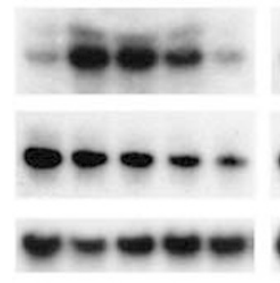

-

o 12243648

FM-516

$\begin{array}{lllll}0 & 12 & 24 & 36 & 48\end{array}$

(h)

-

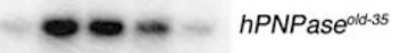

$+000-\infty$

$0-\infty \mathrm{c}-m y c$

$\mathrm{ceces}$

ereve

$\omega+\infty-\infty$

We GAPDH

b

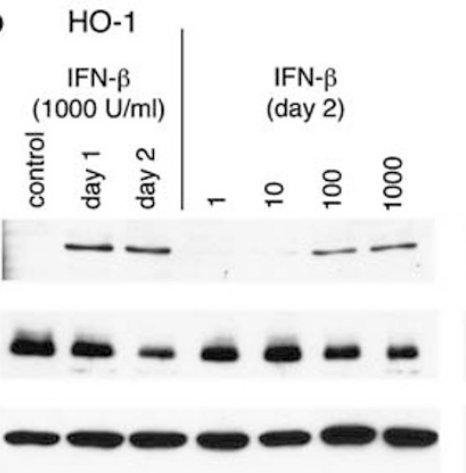

WM35
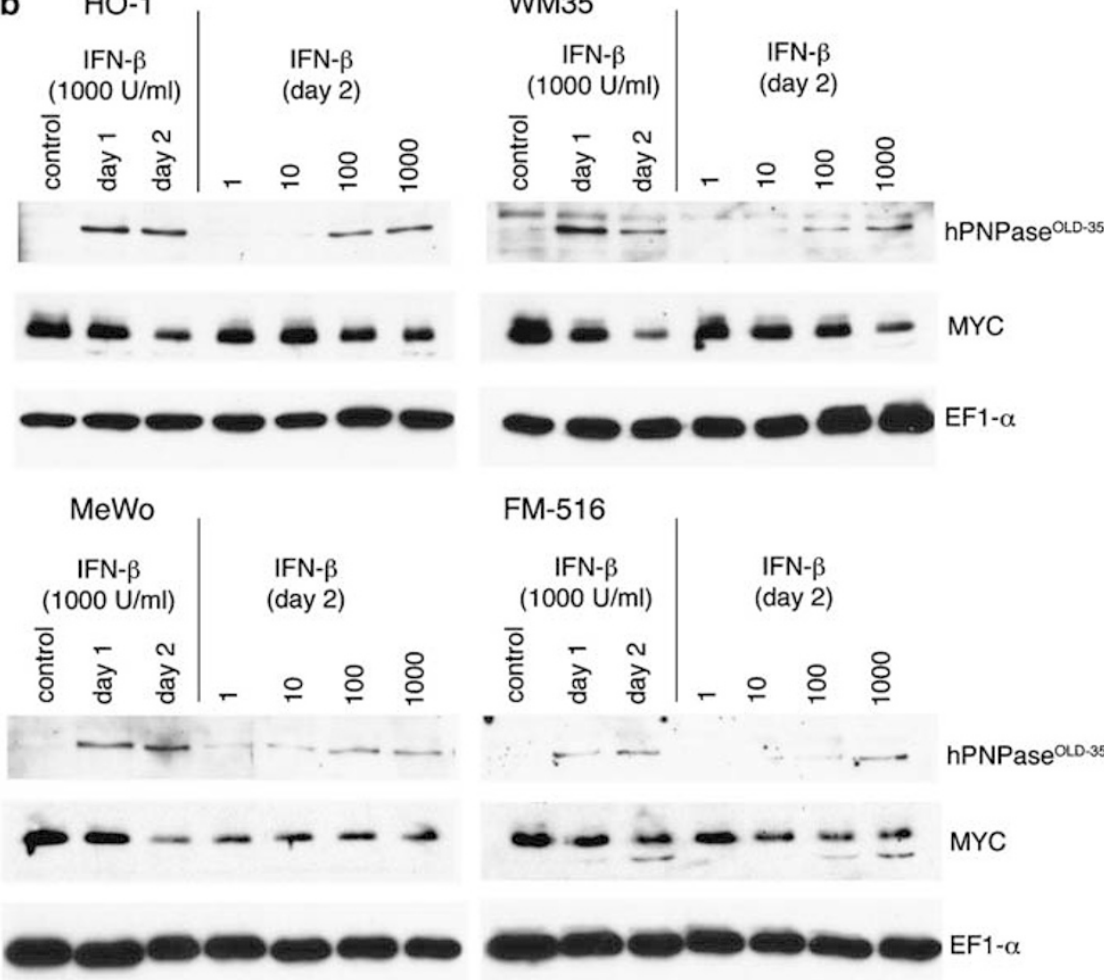

FM-516

IFN-

$(1000 \mathrm{U} / \mathrm{ml}) \quad$ (day 2)

흔

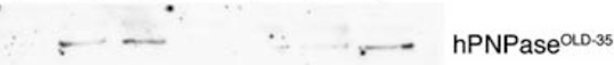

$\Leftrightarrow-\infty-\infty$ M MYC

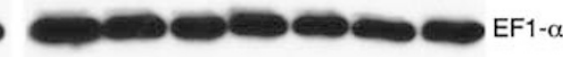

C

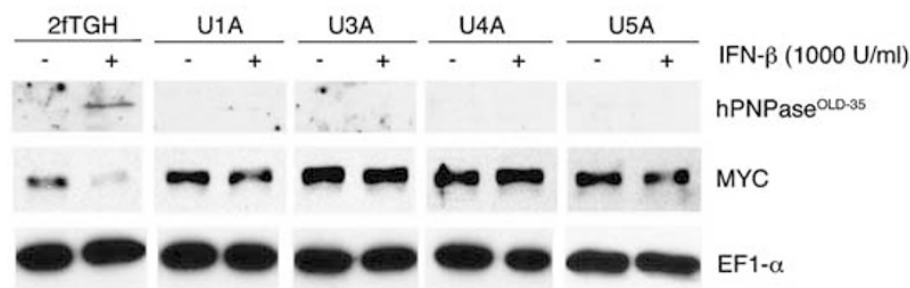

Figure 1 Treatment with IFN- $\beta$ upregulates $h P N P a s e^{\text {old- }-35}$ and downregulates c-myc mRNAs and proteins. (a) The various cell lines were treated with IFN- $\beta$ (1000 U/ $\mathrm{ml}$ ) for the indicated periods of time and the expression of $h P N P a s e^{o l d-35}, \mathrm{c}-m y c$ and GAPDH mRNAs was analyzed by Northern blot analysis. (b) The indicated cells were treated with IFN- $\beta(1000 \mathrm{U} / \mathrm{ml})$ for 1 and 2 days or with $1,10,100$ or $1000 \mathrm{U} / \mathrm{ml}$ of IFN- $\beta$ for 2 days and the expression of $h P N P a e^{\text {old }-35}$, Myc and EF1- $\alpha$ proteins was analyzed by Western blot analysis. (c) 2fTGH human fibrosarcoma cells and its four variants, U1A (Tyk2-), U3A (STAT1-), U4A (JAK1-) and U5A (IFN2AR-), were treated with IFN- $\beta(1000 \mathrm{U} / \mathrm{ml})$ for 2 days and the expression of the indicated proteins was analyzed by Western blot analysis

in its four variants, U1A (Tyk2-), U3A (STAT1-), U4A (JAK1-) and U5A (IFNAR2-), which have mutations in different molecules involved in the IFN-signaling pathway. ${ }^{13}$ As shown in Figure $1 \mathrm{C}$, the upregulation of hPNPase old-35 $^{-3}$ and downregulation of Myc by IFN- $\beta$ were observed only in parental 2fTGH cells but not in its mutant clones, which are nonresponsive to type I IFN.

\section{IFN- $\beta$ inhibits growth of melanoma cells and melanocytes}

The effect of IFN- $\beta$ on the growth of HO-1, WM35, MeWo and FM- 516 cells was analyzed by standard MTT cell survival assays (Figure 2a). Cells were treated with 1, 10, 100, 1000 and $2000 \mathrm{U} / \mathrm{ml}$ of IFN- $\beta$ for up to 6 days. HO-1, WM-35 and 


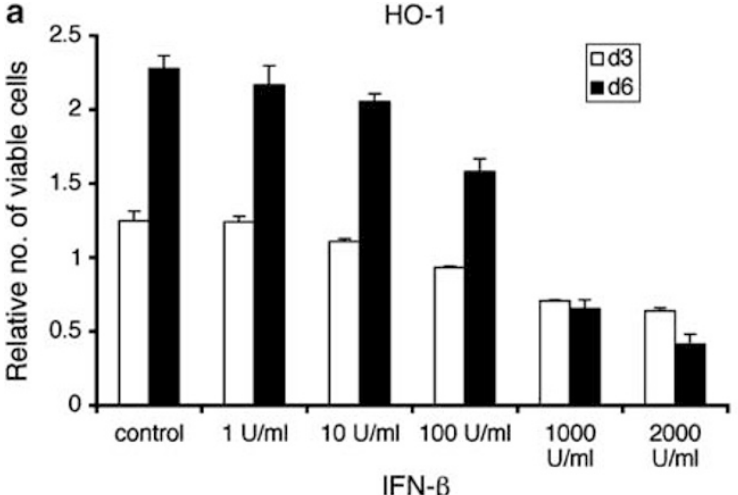

IFN- $\beta$

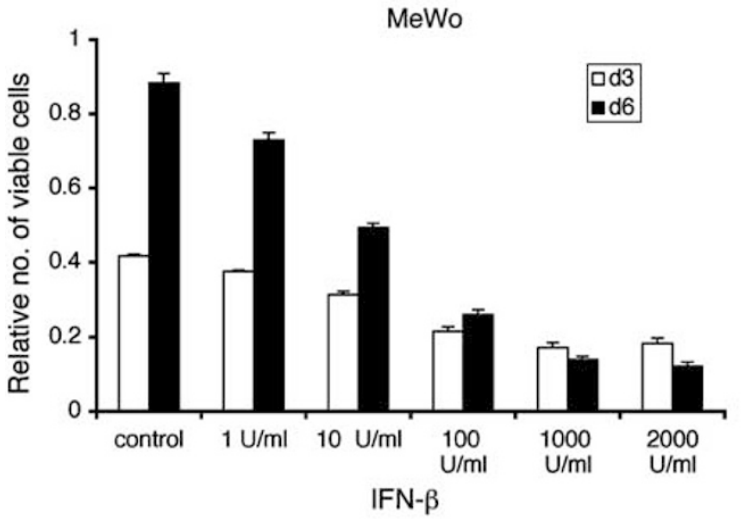

IFN- $\beta$

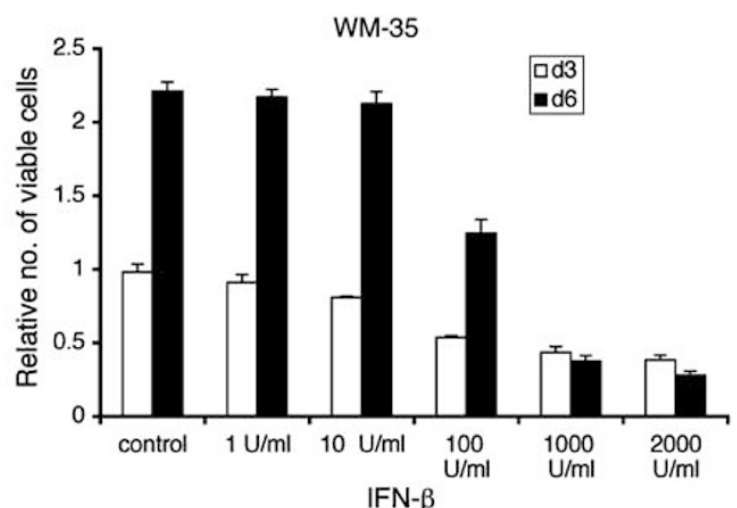

FM-516

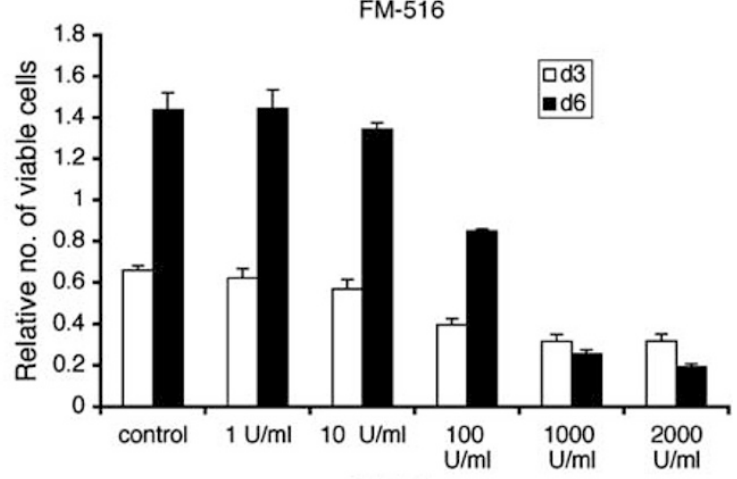

IFN- $\beta$

b

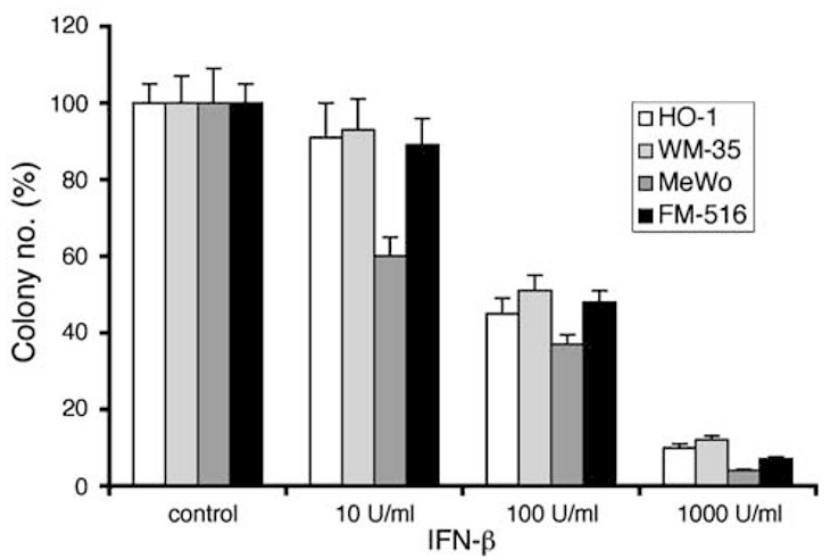

Figure 2 IFN- $\beta$ treatment inhibits growth and colony formation of human melanoma cells and immortalized human melanocytes. (a) The different cell types were treated with the indicated concentrations of IFN- $\beta$ and cell viability was assessed by standard MTT assay on days 3 and 6 post-treatment. The data represent the mean \pm S.D. of three independent experiments, each performed in octaplicates. (b) The different cells were plated in a 6 -cm dish at a density of 1000 cells/dish and then treated with the indicated concentrations of IFN- $\beta$. Colonies were counted after 2 weeks. At least four dishes were used for each data point in each experiment. The data represent the mean \pm S.D. of two independent experiments

FM-516 cells did not respond to 1 or $10 \mathrm{U} / \mathrm{ml}$ of IFN- $\beta$. With $100 \mathrm{U} / \mathrm{ml}$, there was a significant inhibition in cell growth and, with 1000 and $2000 \mathrm{U} / \mathrm{ml}$, there was $\sim 90 \%$ inhibition in growth 6 days after IFN- $\beta$ treatment. The growth of MeWo cells was significantly inhibited even with $1 \mathrm{U} / \mathrm{ml}$ of IFN- $\beta$, which became marked with 100 or more $\mathrm{U} / \mathrm{ml}$ of IFN- $\beta$. These studies document a direct correlation between gene expression changes and the levels of IFN- $\beta$ required to evoke growth inhibition in specific target cells. This finding is particularly relevant in the case of MeWo cells in which corresponding changes could be observed even with $1 \mathrm{U} / \mathrm{ml}$ of IFN- $\beta$.
The results obtained using cell viability assays were confirmed by colony formation assays (Figure 2b). In HO-1, WM-35 and FM-516 cells colony formation was significantly inhibited with $100 \mathrm{U} / \mathrm{ml}$ of IFN- $\beta$ and, with $1000 \mathrm{U} / \mathrm{ml}$, the colony formation was inhibited by $>90 \%$. In the case of MeWo cells, $10 \mathrm{U} / \mathrm{ml}$ of IFN- $\beta$ significantly inhibited colony formation and with $1000 \mathrm{U} / \mathrm{ml}$ of IFN- $\beta$ colony formation was inhibited by $>95 \%$.

Cell cycle analysis was performed to characterize growth inhibition. IFN- $\beta$ treatment $(1000 \mathrm{U} / \mathrm{ml})$ in $\mathrm{HO}-1$, WM-35, MeWo and FM-516 cells resulted in initial (day 1 ) cell cycle arrest in the $G_{1}$ phase of the cell cycle, with a concomitant 
decrease in the DNA synthesis phase as substantiated by the reduction in S phase (Table 1). With longer exposure to IFN- $\beta$, the cells gradually became apoptotic, as evidenced by a steady increase in the sub- $G_{1}\left(A_{0}\right)$ cell population.

\section{hPNPase ${ }^{\text {old-35 }}$ regulates IFN- $\beta$-mediated downregulation of Myc}

Since $h P N P a s e^{\text {old-35 }}$ is a $3^{\prime}, 5^{\prime}$ exoribonuclease and one of its substrates is c-myc mRNA, we tested whether $h P N P a s e^{\text {old }-35}$, induced by IFN- $\beta$, promotes Myc downregulation. We have identified siRNA active in downregulating hPNPase ${ }^{\text {old }-35}$ and created a lentivirus expressing this siRNA. Stable clones in an $\mathrm{HO}-1$ background expressing either control siRNA or

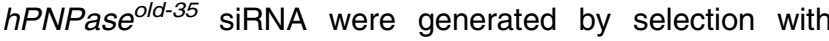
blasticidin. As shown in Figure 3A, three clones, clone 1, 4 and 5, which express hPNPase old-35-siRNA, were identified, which significantly inhibited IFN- $\beta$ induction of $h P N P a s e^{\text {old }-35}$, with clone 1 being the most efficient, producing almost $100 \%$ inhibition in hPNPase ${ }^{\text {old-35 }}$ induction. The clone expressing control siRNA retained its ability to induce $h P N P a s e^{\text {old-35 }}$ following IFN- $\beta$ treatment. Remarkably, while the parental $\mathrm{HO}-1$ cells and control-siRNA-expressing clone could downregulate Myc in response to IFN- $\beta$ treatment, all three

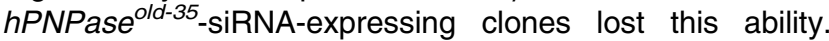
However, these clones retained their ability to respond to IFN- $\beta$, as evidenced by the induction of another IFN-inducible gene mda-5. These findings indicate that $h P N P a s e^{\text {old }-35}$ specifically mediates downregulation of Myc, but not the modulation of other genes by IFN- $\beta$. The observation of similar responses in multiple clones rules out the possibility that the observed effects are simply a consequence of clonal variability in response to IFN- $\beta$.

The half-life of $c$ - $m y c$ mRNA with or without IFN- $\beta$ treatment was analyzed in $\mathrm{HO}-1$ cells and control siRNA and

Table 1 IFN- $\beta$ induces $G_{1}$ cell cycle arrest and apoptosis in melanoma cells and normal melanocytes

\begin{tabular}{|c|c|c|c|c|c|c|}
\hline & Day 1 & Day 2 & Day 3 & Day 1 & Day 2 & Day 3 \\
\hline & \multicolumn{3}{|c|}{$G_{1}$} & \multicolumn{3}{|c|}{$S$} \\
\hline HO-1 control & 50.6 & 44.4 & 45.45 & 9.28 & 11.37 & 11.42 \\
\hline $\mathrm{HO}-1$ IFN- $\beta$ & $59.05^{\star}$ & $55.8^{\star}$ & 43.33 & $6.97^{*}$ & $6.77^{*}$ & $6.73^{\star}$ \\
\hline WM-35 control & 48.94 & 47.57 & 55.59 & 8.21 & 12.82 & 8.86 \\
\hline WM-35 IFN- $\beta$ & $60.8^{\star}$ & 43.26 & 30.91 & $6.2^{\star}$ & $6.54^{\star}$ & $4.65^{\star}$ \\
\hline MeWo control & 48.91 & 53.19 & 40.7 & 9.47 & 13.58 & 10.53 \\
\hline MeWo IFN- $\beta$ & $56.05^{\star}$ & 58.13 & 35.81 & 7.89* & $6.94^{\star}$ & $4.65^{\star}$ \\
\hline FM-516 control & 43 & 50.59 & 51.11 & 13.6 & 11.11 & 8.42 \\
\hline \multirow[t]{2}{*}{ FM-516 IFN- $\beta$} & $50.86^{\star}$ & 47.12 & 38.54 & $8.6^{\star}$ & $6.47^{\star}$ & $5.31 *$ \\
\hline & \multicolumn{3}{|c|}{$G_{2}+M$} & \multicolumn{3}{|c|}{$A_{O}$} \\
\hline $\mathrm{HO}-1$ control & 37.88 & 47.09 & 38.28 & 1.61 & 1.14 & 0.75 \\
\hline $\mathrm{HO}-1$ IFN- $\beta$ & 29.83 & 31.65 & 31.12 & 1.60 & $5.78^{\star}$ & $13.81^{*}$ \\
\hline WM-35 control & 38.82 & 35.56 & 33.55 & 1.35 & 1.95 & 1.48 \\
\hline WM-35 IFN- $\beta$ & 29.51 & 38.59 & 33.9 & 1.51 & $8.87^{*}$ & $21.87^{\star}$ \\
\hline MeWo control & 41.33 & 30.02 & 46.25 & 0.71 & 1.68 & 2.52 \\
\hline MeWo IFN- $\beta$ & 33.4 & 26.2 & 44.32 & 1.4 & $5.89^{\star}$ & $15.22^{\star}$ \\
\hline FM-516 control & 40.83 & 35.31 & 37.39 & 2.57 & 2.99 & 3.08 \\
\hline FM-516 IFN- $\beta$ & 37.64 & 40.48 & 42.67 & 2.9 & $5.93^{*}$ & $13.48^{\star}$ \\
\hline
\end{tabular}

HO-1, WM-35, MeWo and FM-516 cells were treated with IFN- $\beta(1000 \mathrm{U} / \mathrm{ml})$ and cell cycle was analyzed by flow cytometry on day 1,2 and 3 post-treatment. Bold IFN- $\beta$-treated data points marked with asterisks indicate significant differences $(P<0.01)$ from the control data points
hPNPase ${ }^{\text {old-35}}$-siRNA-expressing clones (Figure 3b). The cells were treated with IFN- $\beta(1000 \mathrm{U} / \mathrm{ml})$ for $24 \mathrm{~h}$ and then exposed to Actinomycin D (Act D; $5 \mu \mathrm{g} / \mathrm{ml}$ ) for $0.5-8 \mathrm{~h}$ (Figure $3 b$ ). In the untreated cells, the half-life of c-myc mRNA was $\sim 1 \mathrm{~h}$. In HO-1 cells and control siRNA-expressing clones, IFN- $\beta$ treatment resulted in significant downregulation of $c-m y c$ mRNA so that by $0.5 \mathrm{~h}$ of Act D treatment no c-myc mRNA could be detected in these cells. This downregulation correlated with upregulation of $h P N P a s e^{\text {old }-35}$ mRNA that had a half-life of $\sim 4 \mathrm{~h}$. In contrast, IFN- $\beta$ treatment did not induce hPNPase ${ }^{\text {old }-35}$ mRNA expression in hPNPase ${ }^{\text {old-35 }}$-siRNAexpressing clones and the half-life of c-myc mRNA remained

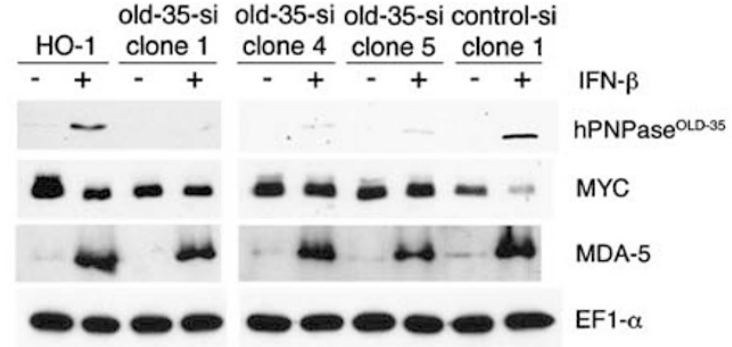

b Control IFN- $\beta(1000 \mathrm{U} / \mathrm{ml})$ $\begin{array}{lllllllllllll}0 & 0.5 & 1 & 2 & 4 & 8 & 0 & 0.5 & 1 & 2 & 4 & 8 & \text { (h) Act D }\end{array}$

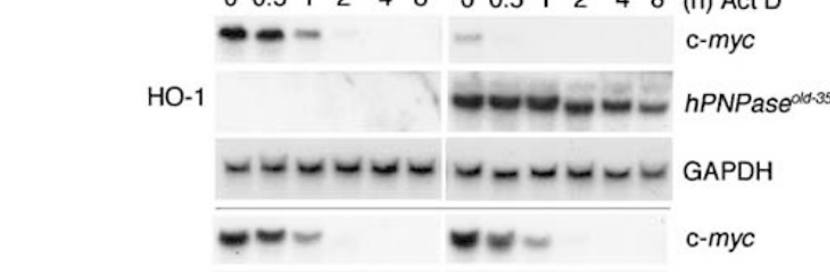

Old-35-si clone 1 hPNPase ald-35

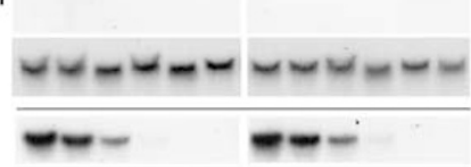

GAPDH c-myc

Old-35-si clone 4 hPNPase ald-35

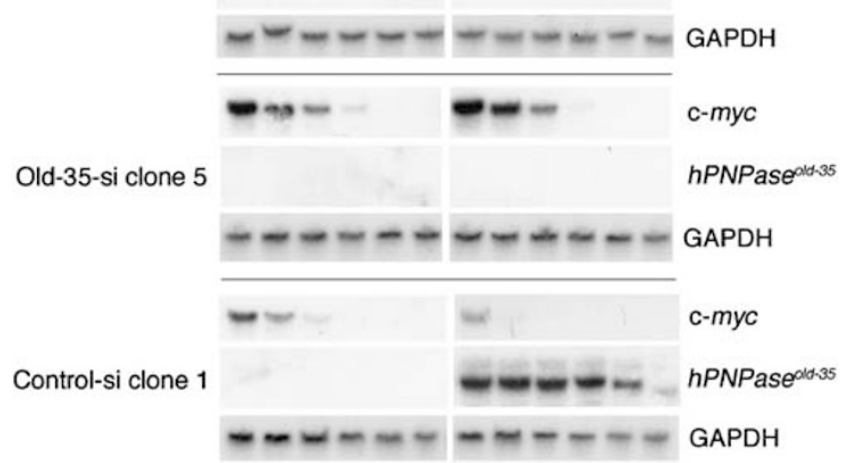

Figure 3 HO-1 clones expressing $h P N P a s e^{\text {old }-35}$ siRNA are resistant to IFN- $\beta$ mediated c-myc downregulation. (a) Parental HO-1 cells, HO-1 clones expressing hPNPase $e^{\text {old-35 }}$ siRNA (old-35-si clone 1, clone 4 and clone 5) and HO-1 clones expressing control siRNA (control-si clone 1) were treated with IFN$\beta(1000 \mathrm{U} / \mathrm{ml})$ for 2 days and the expression of $h P N P a s e^{\text {old }-35}$, Myc, MDA-5 and EF1- $\alpha$ proteins was analyzed by Western blot analysis. (b) For analysis of the half-life of c-myc mRNA, cells were either untreated or treated with IFN- $\beta$ $(1000 \mathrm{U} / \mathrm{ml})$ for $24 \mathrm{~h}$ and then exposed to Act-D $(5 \mu \mathrm{g} / \mathrm{ml})$ for $0.5,1,2,4$ and $8 \mathrm{~h}$, after which the cells were harvested for total RNA extraction and Northern blot analysis using the indicated probes 
unchanged when compared to control untreated cells (Figure $3 b$ ). These findings indicate that under basal condition

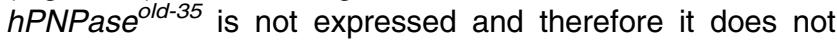
affect the turnover of $c-m y c$ mRNA. However, upon IFN- $\beta$ treatment this enzyme is induced and it degrades $c-m y c$ mRNA.

\section{Resistance of $h P N P a s e^{\text {old-35 }}$-siRNA clones to IFN- $\beta$-mediated growth inhibition}

Overexpression of hPNPase ${ }^{\text {old-35 }}$ induces growth inhibition and apoptosis in melanoma cells and c-myc is a positive regulator of cell growth, allowing cells to traverse the $G_{1}$ phase of the cell cycle. Based on these considerations, we tested whether the lack of these two events in hPNPase ${ }^{\text {old-35 }}$-siRNAexpressing clones would render them resistant to IFN- $\beta$ mediated growth inhibition. As shown in Figure 4b, while the parental HO-1 cells and control siRNA-expressing clones were sensitive to IFN- $\beta$ treatment, as monitored by standard MTT assays, the hPNPase ${ }^{\text {old-35}}$-siRNA-expressing clones showed significant resistance to IFN- $\beta$, which became more pronounced after 6 days of IFN- $\beta$ treatment. These findings were confirmed by colony formation assays, which also demonstrated significant resistance of $h P N P a s e^{\text {old-35 }}$-siRNAexpressing clones to IFN- $\beta$-induced inhibition of colony formation (Figure 5).

The results obtained from cell survival and colony formation assays were confirmed by cell cycle analysis using flow cytometry. As shown in Figure 6 and Table 2, the parental $\mathrm{HO}-1$ cells and control siRNA-expressing clones showed an initial $\mathrm{G}_{1}$ arrest and eventually cells underwent apoptosis. However,

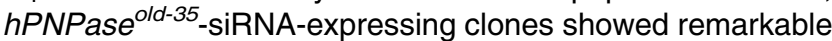
resistance to growth inhibition by IFN- $\beta$, with no statistically significant increase in the $G_{1}$ phase or the number of $A_{0}$ cells. In these contexts, blocking hPNPase ${ }^{\text {old-35 }}$ expression prevents cell cycle arrest and apoptosis induced by IFN- $\beta$.

To confirm that the mechanism underlying the resistance of $h P N P a$ ald $^{\text {ol } 35}$-siRNA-expressing clones to IFN- $\beta$ is mediated by their inability to downregulate $c-m y c, \mathrm{HO}-1$ cells and

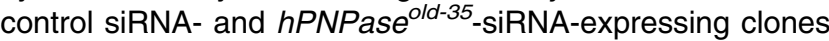
were transfected with either control or c-myc siRNA and b

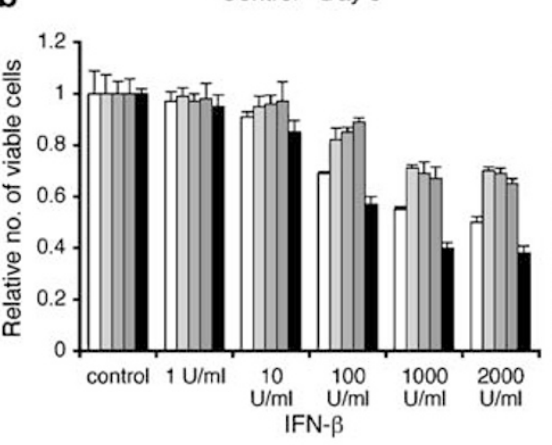

Control - Day 6

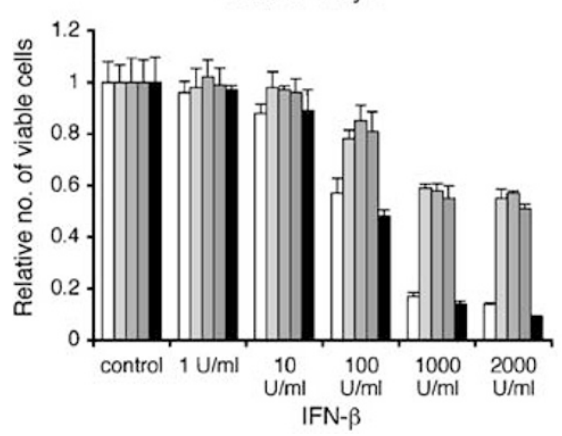

a
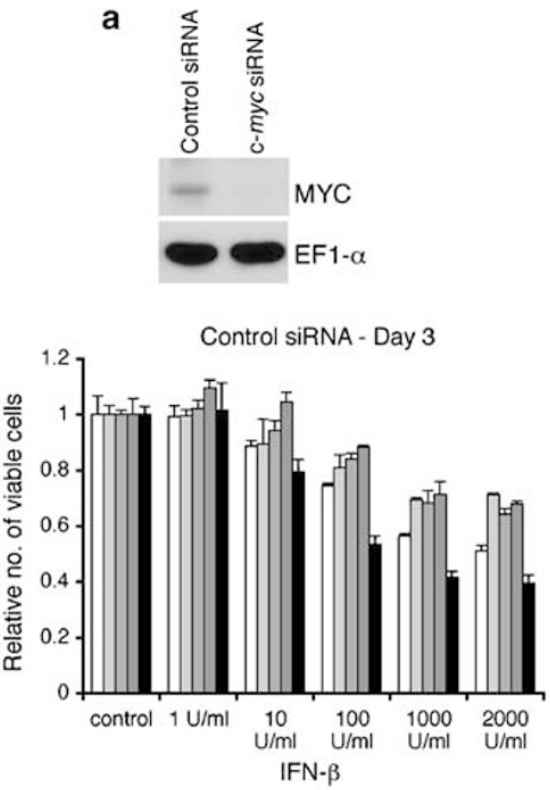

Control siRNA - Day 6

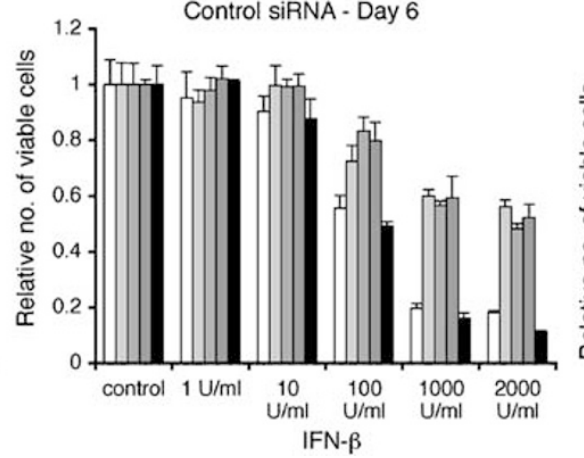

c-myc siRNA - Day 3

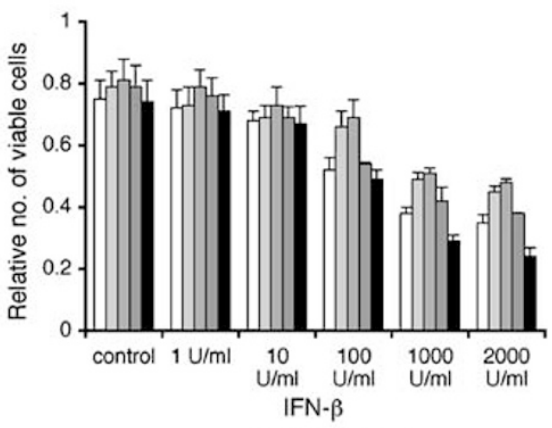

c-myc siRNA - Day 6

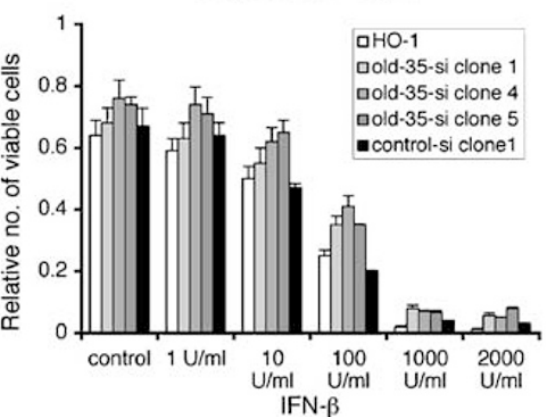

Figure 4 HO-1 clones expressing hPNPase ${ }^{o l d-35}$ siRNA are resistant to IFN- $\beta$-mediated growth inhibition that can be reversed by c-myc siRNA. (a) HO- 1 cells were transfected with either control siRNA or c-myc siRNA and the expression of Myc and EF1- $\alpha$ proteins was analyzed by Western blot analysis. (b) HO-1 cells, HO-1 clones expressing hPNPase ${ }^{\text {old-35 }}$ siRNA (old-35-si clone 1, clone 4 and clone 5) and HO-1 clones expressing control siRNA (control-si clone 1) were either mock-transfected (control) or transfected with control siRNA or c-myc siRNA and then treated with the indicated concentrations of IFN- $\beta$, and cell viability was assessed by standard MTT assay on day 3 and 6 post-treatment. The data represent the mean \pm S.D. of three independent experiments, each performed in octaplicates 

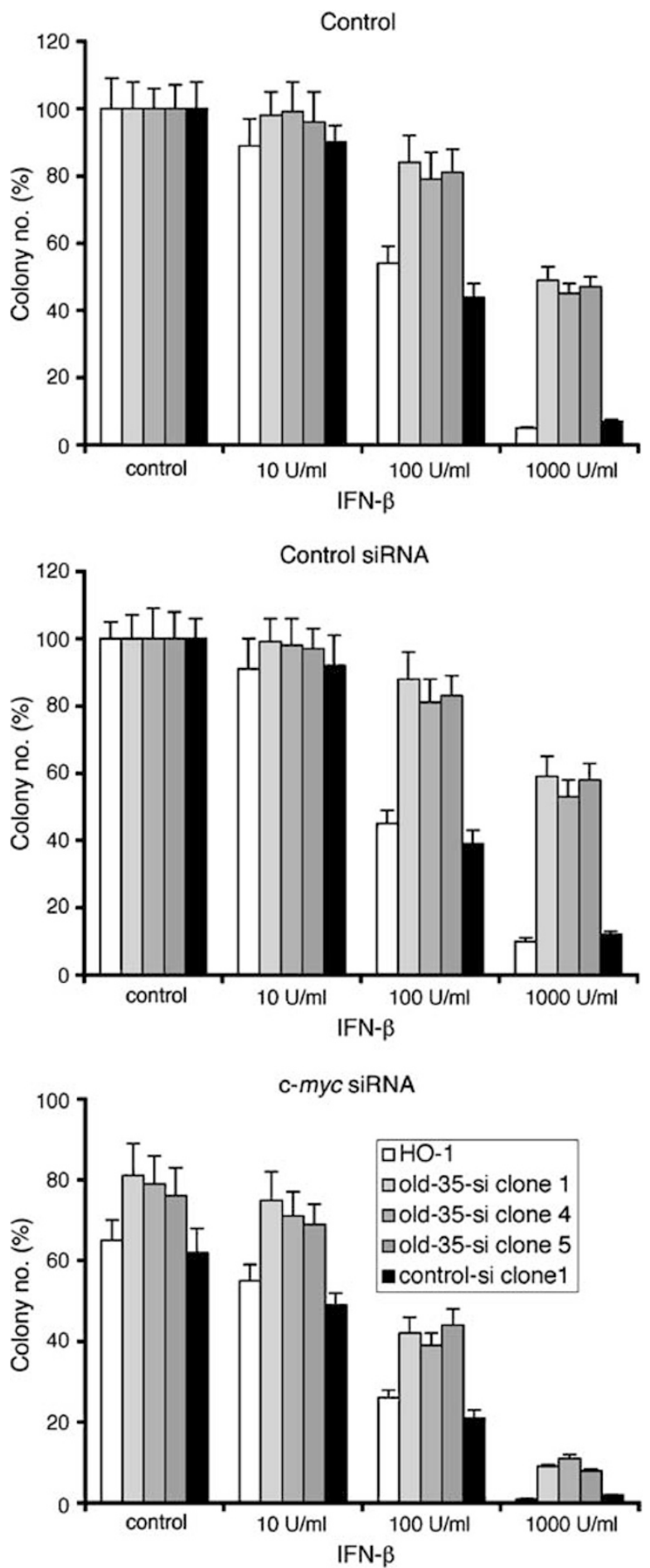

Figure 5 HO- 1 clones expressing $h P N P a s e^{\text {old }-35}$ siRNA are resistant to IFN- $\beta$ mediated colony formation inhibition that can be reversed by c-myc siRNA. HO-1 cells, HO-1 clones expressing hPNPase ${ }^{\text {old-35 }}$ siRNA (old-35-si clone 1, clone 4 and clone 5) and $\mathrm{HO}-1$ clones expressing control siRNA (control-si clone 1) were either mock-transfected (control) or transfected with control siRNA or c-myc siRNA and then treated with the indicated concentrations of IFN- $\beta$ and colony formation assay was performed. Colonies were counted after 2 weeks. At least four dishes were used for each data point in each experiment. The data represent the mean + S.D. of two independent experiments treated with IFN- $\beta$, and cell viability, colony formation and cell cycle analyses were performed. Transfection of c-myc siRNA resulted in marked downregulation of Myc protein (Figure 4a), indicating the authenticity of its function. Cell viability and colony formation ability were similar between control untransfected cells and control siRNA-transfected cells (Figures $4 \mathrm{~b}$ and 5), with hPNPase ${ }^{\text {old-35}}$-siRNA-expressing clones showing resistance to IFN- $\beta$ and $\mathrm{HO}-1$ cells and control siRNA-expressing clones showing sensitivity to IFN- $\beta$. Transfection of $c-m y c$ siRNA alone reduced the cell viability and colony formation ability of all the cell lines, and together with IFN- $\beta$ markedly inhibited the cell viability and colony formation

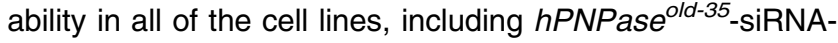
expressing clones (Figures $4 \mathrm{~b}$ and 5 ). Cell cycle analysis also revealed that transfection of c-myc siRNA rendered hPNPase ${ }^{\text {old-35}}$-siRNA-expressing clones susceptible to IFN- $\beta$ mediated cell cycle arrest and apoptosis (Table 2). In total, these findings indicate that inhibition of c-myc downregulation in hPNPase old-35-siRNA-expressing clones confers their resistance to growth inhibition by IFN- $\beta$.

\section{Resistance of c-myc-overexpressing clones to IFN- $\beta$-mediated growth inhibition}

We next evaluated the involvement of c-myc downregulation in IFN- $\beta$-mediated growth inhibition. For this purpose, stable Myc-overexpressing $\mathrm{HO}-1$ clones (HO-1-Myc) were developed by transfection with a c-myc expression vector and selection with hygromycin. Control hygromycin-resistant clones (HO-1-Hygro) were similarly generated. Figure 7a provides data from two representative Myc-overexpressing $\mathrm{HO}-1$ clones. IFN- $\beta$ treatment for 3 days resulted in marked downregulation of endogenous Myc protein in $\mathrm{HO}-1-\mathrm{Hyg}$ ro clones (Figure 7a). However, the exogenous Myc protein in $\mathrm{HO}-1-M y c$ clones was not significantly downregulated by IFN- $\beta$. The $c-m y c$ expression construct contains only the open reading frame and not the $3^{\prime}$ or $5^{\prime}$ untranslated regions (UTR) of the cDNA. The inability of IFN- $\beta$ to downregulate exogenous c-myc indicates that the $3^{\prime}$-UTR of the endogenous $c-m y c$ sequence might confer its sensitivity to hPNPase $e^{\text {old }-35}$ since hPNPase old-35 is a $3^{\prime}, 5^{\prime}$ exoribonuclease. The growth of the HO-1-Hygro clones (clones 1 and 4) was significantly inhibited by IFN- $\beta(1000 \mathrm{U} / \mathrm{ml})$ treatment, as documented by cell viability assays (Figure 7c). HO-1-Myc clones overexpressing Myc provided partial but significant protection from IFN- $\beta$-mediated growth inhibition (Figure $7 \mathrm{c}$ ). These findings were also confirmed by colony formation assays (Figure 7b). HO-1-Myc clones, but not HO-1-Hygro clones, showed resistance to inhibition of colony formation by IFN- $\beta$. These results implicate IFN- $\beta$ modulation of $\mathrm{c}-m y c$ as an important factor associated with IFN- $\beta$-induced growth suppression in $\mathrm{HO}-1$ cells.

These interesting findings were corroborated by cell cycle analysis. Treatment with IFN- $\beta$ induced an initial $\mathrm{G}_{1}$ arrest and eventually apoptosis in $\mathrm{HO}-1$-Hygro clones (Table 3 ). The $\mathrm{HO}-1-M y c$ clones showed a slight increase in the percentage of $\mathrm{G}_{1}$ phase and apoptotic cells following IFN- $\beta$ treatment, which was not statistically significant. These findings indicate that both upregulation of $h P N P a s e^{\text {old-35 }}$ and downregulation 


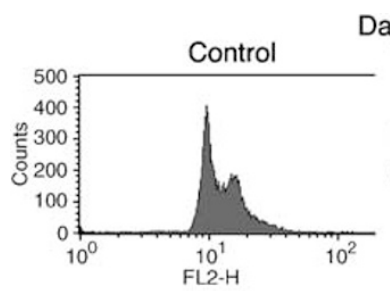

Day 1
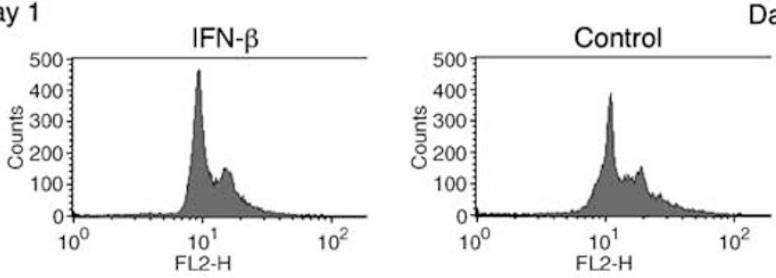

Day 3

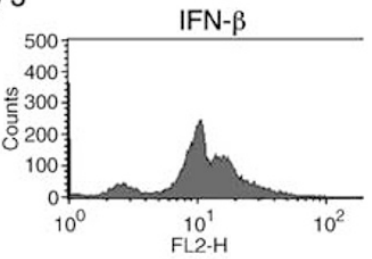

$\mathrm{HO}-1$
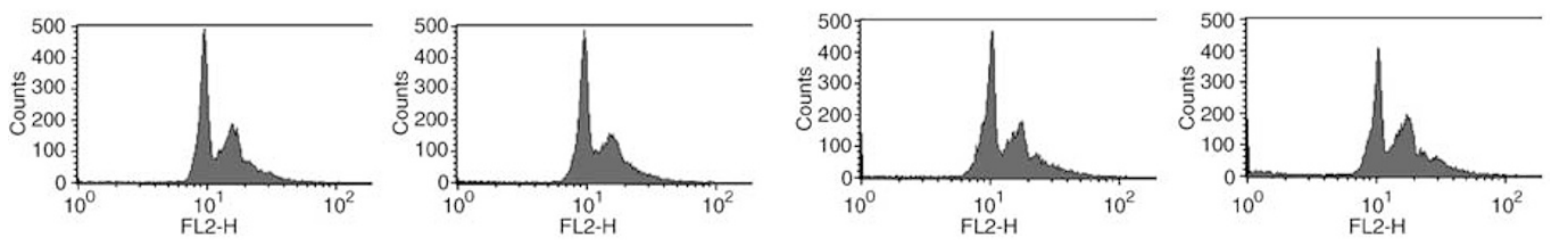

Old-35-si

clone 1
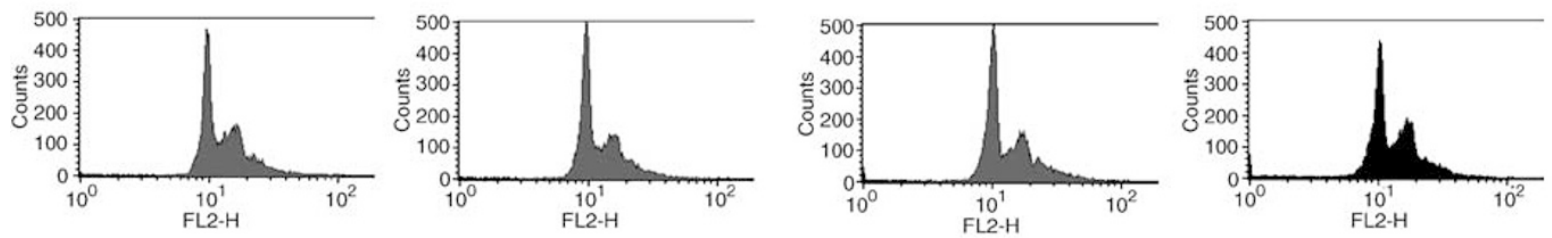

Old-35-si clone 4
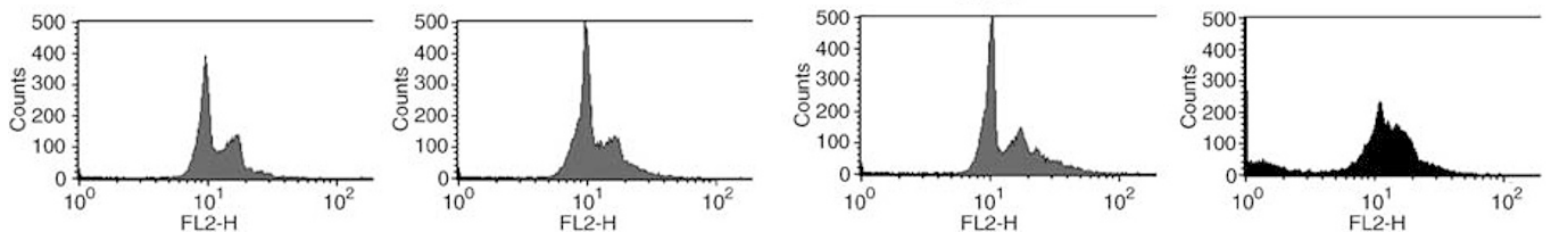

Control-si

clone 1

Figure $6 \mathrm{HO}-1$ clones expressing hPNPase ${ }^{\text {old }-35}$ siRNA are resistant to IFN- $\beta$-induced $\mathrm{G}_{1}$ cell cycle arrest and apoptosis. HO-1 cells, HO-1 clones expressing hPNPase ${ }^{\text {old-35 }}$ siRNA (old-35-si clone 1 and clone 4) and HO-1 clones expressing control siRNA (control-si clone 1) were treated with IFN- $\beta$ (1000 U/ml) and cell cycle was analyzed by flow cytometry on day 1 and 3 post-treatment

of $c-m y c$ are central events in mediating the ability of IFN- $\beta$ to inhibit growth in human melanoma cells (Figure 8 ).

\section{Discussion}

Microarray studies have revealed a plethora of genes that are modulated by IFN treatment ${ }^{14}$ (http://bioinfo.cnio.es/data/ oncochip/). IFNs can directly affect gene expression by ISRE and GAS sequences in the promoters of target genes. ${ }^{1}$ In addition, IFNs can also affect gene expression by their ability to induce proteins involved in RNA metabolism, such as $2^{\prime}$, 5'-oligoadenylate synthetase/RNase L, double-stranded RNA-dependent protein kinase (PKR), melanoma differentiation-associated gene-5 (mda-5), retinoic acid-inducible gene-I

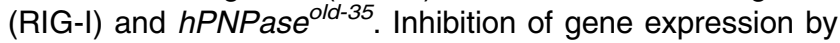
IFNs at a post-transcriptional level has been described for the heavy chain of immunoglobulin $m u,{ }^{15}$ the IL-4 receptor ${ }^{16}$ and c-myc ${ }^{11,12}$ the focus of the present studies.

The observation that type I IFN selectively reduces c-myc mRNA has been described in multiple studies using several model cell culture systems. Jonak and Knight first hypothesized that IFN- $\beta$ mediated downregulation of c-myc mRNA might mediate growth inhibition in Daudi human lymphoblastoid cells. ${ }^{11}$ As a follow-up study, Dani et al. demonstrated in Daudi cells that IFN $\alpha / \beta$ did not affect the transcription rate of c-myc mRNA, but rather reduced the half-life of this mRNA. ${ }^{12}$ A post-transcriptional destabilization of c-myc mRNA as a mechanism of type I IFN-mediated c-myc suppression has also been described in colon carcinoma cells. ${ }^{17}$ It was shown that, during terminal differentiation of hematopoietic cells, autocrine IFN- $\beta$ induces c-myc suppression and induces $\mathrm{G}_{0} / \mathrm{G}_{1}$ arrest in these cells. ${ }^{18}$ Additionally, previous studies from our laboratory documented that IFN- $\beta$ and MEZ-induced terminal differentiation of human melanoma cells also correlated with downregulation of $c-m y c$ mRNA. ${ }^{19}$ Moreover, studies in different cell types consistently describe the ability of type I IFN to reduce c-myc expression. However, the effect of IFN- $\gamma$ on c-myc expression varies in different cell contexts. In HeLa cells, treatment with IFN- $\alpha$ decreased, while IFN- $\gamma$ increased c-myc expression. ${ }^{20}$ In a murine myeloid cell line, IFN- $\gamma$ inhibited c-myc gene expression by impairing the splicing process. ${ }^{21}$ Another report described the importance of Stat-1 in IFN- $\gamma$-mediated downregulation of c-myc. Studies employing wild type and Stat-1-null mouse embryonic fibroblasts identified a GAS element in the c-myc promoter that was necessary, but not sufficient, to suppress c-myc expression in wild-type cells. ${ }^{22}$

Although a consensus exists that type I IFNs induce posttranscriptional modulation of c-myc mRNA, the molecular mechanism underlying this process is unclear. Different components of IFN-inducible RNA degradation machinery have been implicated in this action. In colon carcinoma cells, $2^{\prime}, 5^{\prime}$-oligoadenylate synthetase/RNase $L$ system is believed to regulate IFN- $\beta$-mediated post-transcriptional processing of c-myc mRNA. ${ }^{17}$ In M1 murine myeloid leukemia cells, PKR has been shown to mediate type I IFN-induced c-myc suppression. ${ }^{23} \mathrm{~A}$ recent report indicates that in mouse 
Table 2 HO-1 clones expressing hPNPase ${ }^{\text {old-35 }}$ siRNA are resistant to IFN- $\beta$-induced $\mathrm{G}_{1}$ cell cycle arrest and apoptosis, which can be inhibited by c-myc siRNA

\begin{tabular}{|c|c|c|c|c|c|c|c|c|c|}
\hline & \multicolumn{3}{|c|}{ Day 1} & \multicolumn{3}{|c|}{ Day 2} & \multicolumn{3}{|c|}{ Day 3} \\
\hline & Control & $\begin{array}{l}\text { Control } \\
\text { siRNA }\end{array}$ & $\begin{array}{l}c-m y c \\
\text { siRNA }\end{array}$ & Control & $\begin{array}{c}\text { Control } \\
\text { siRNA }\end{array}$ & $\begin{array}{l}c-m y c \\
\text { siRNA }\end{array}$ & Control & $\begin{array}{l}\text { Control } \\
\text { siRNA }\end{array}$ & $\begin{array}{l}c-m y c \\
\text { siRNA }\end{array}$ \\
\hline $\begin{array}{l}\text { HO-1 control } \\
\text { HO-1 IFN- } \beta \\
\text { Old-35-si clone } 1 \text { control } \\
\text { Old-35-si clone } 1 \text { IFN- } \beta \\
\text { Old-35-si clone } 4 \text { control } \\
\text { Old-35-si clone } 4 \text { IFN- } \beta \\
\text { Old-35-si clone } 5 \text { control } \\
\text { Old-35-si clone } 5 \text { IFN- } \beta \\
\text { Control-si clone } 1 \text { control } \\
\text { Control-si clone } 1 \text { IFN- } \beta\end{array}$ & $\begin{array}{l}51.1 \\
\mathbf{5 8 . 0 7}^{\star} \\
51.85 \\
53.97 \\
51.31 \\
52.81 \\
50.87 \\
51.23 \\
52.08 \\
\mathbf{6 3 . 0 7}^{\star}\end{array}$ & $\begin{array}{l}51.2 \\
60.54^{\star} \\
50.26 \\
52.84 \\
50.28 \\
51.36 \\
52.36 \\
50.62 \\
50.26 \\
61.56^{\star}\end{array}$ & $\begin{array}{l}56.48 \\
63.25^{\star} \\
55.45 \\
61.58^{\star} \\
57.42 \\
60.58^{\star} \\
54.23 \\
59.21^{*} \\
57.48 \\
64.48^{\star}\end{array}$ & $\begin{array}{l}43.8 \\
55.1^{\star} \\
45.22 \\
46.48 \\
48.02 \\
48.16 \\
44.59 \\
43.96 \\
50.53 \\
52.21\end{array}$ & $\begin{array}{l}G_{1} \\
43.58 \\
53.48^{\star} \\
46.21 \\
47.85 \\
46.54 \\
47.87 \\
45.81 \\
44.58 \\
49.23 \\
47.81\end{array}$ & $\begin{array}{l}\mathbf{5 2 . 6 4}^{\star} \\
\mathbf{5 7 . 4 8}^{\star} \\
50.21 \\
58.64^{\star} \\
51.64 \\
\mathbf{5 6 . 8 7}^{\star} \\
52.34 \\
\mathbf{5 4 . 4 9}^{\star} \\
54.65 \\
\mathbf{5 9 . 4 2}^{\star}\end{array}$ & $\begin{array}{l}45.09 \\
44.13 \\
51.56 \\
47.31 \\
49.17 \\
45.59 \\
47.85 \\
45.62 \\
49.48 \\
41.53\end{array}$ & $\begin{array}{l}44.52 \\
41.26 \\
49.85 \\
44.56 \\
44.62 \\
46.32 \\
46.17 \\
42.89 \\
47.25 \\
42.68\end{array}$ & $\begin{array}{l}46.25 \\
44.65 \\
50.25 \\
47.23 \\
47.56 \\
48.35 \\
45.63 \\
47.51 \\
48.62 \\
43.54\end{array}$ \\
\hline $\begin{array}{l}\text { HO-1 control } \\
\text { HO-1 IFN- } \beta \\
\text { Old-35-si clone } 1 \text { control } \\
\text { Old-35-si clone } 1 \text { IFN- } \beta \\
\text { Old-35-si clone } 4 \text { control } \\
\text { Old-35-si clone } 4 \text { IFN- } \beta \\
\text { Old-35-si clone } 5 \text { control } \\
\text { Old-35-si clone } 5 \text { IFN- } \beta \\
\text { Control-si clone } 1 \text { control } \\
\text { Control-si clone } 1 \text { IFN- } \beta\end{array}$ & $\begin{array}{l}9.11 \\
\mathbf{6 . 7 6} \\
8.58 \\
8.1 \\
12 \\
10.48 \\
9.85 \\
9.58 \\
7.74 \\
\mathbf{5 . 9}^{\star}\end{array}$ & $\begin{array}{l}9.54 \\
\mathbf{6 . 1 5} \\
9.14 \\
9.04 \\
11.54 \\
10.29 \\
10.02 \\
9.84 \\
8.29 \\
\mathbf{5 . 6 1}\end{array}$ & $\begin{array}{l}7.19 \\
5.05^{\star} \\
7.24 \\
6.24^{\star} \\
9.32^{\star} \\
7.43^{\star} \\
7.54 \\
6.21^{\star} \\
5.67^{\star} \\
\mathbf{4 . 5 8 ^ { \star }}\end{array}$ & $\begin{array}{c}10.91 \\
6.69^{\star} \\
8.12 \\
8.12 \\
11.02 \\
9.55 \\
9.59 \\
9.09 \\
10.84 \\
7.07^{\star}\end{array}$ & $\begin{array}{c}S \\
10.58 \\
\mathbf{5 . 9 5} \\
9.04 \\
8.88 \\
11.47 \\
10.01 \\
9.69 \\
8.99 \\
9.52 \\
\mathbf{5 . 2 1}^{\star}\end{array}$ & $\begin{array}{l}5.31^{\star} \\
4.28^{\star} \\
7.09 \\
5.98^{\star} \\
8.96 \\
7.13^{\star} \\
7.15 \\
6.07^{\star} \\
5.57 \\
4.38^{\star}\end{array}$ & $\begin{array}{c}11.19 \\
5.98^{\star} \\
6.05 \\
6.02 \\
7.24 \\
6.55 \\
7.88 \\
7.54 \\
9.22 \\
\mathbf{4 . 2 5}^{\star}\end{array}$ & $\begin{array}{c}10.64 \\
\mathbf{5 . 5 6} \\
7.57 \\
7.48 \\
7.95 \\
7.12 \\
7.61 \\
7.18 \\
9.17 \\
\mathbf{4 . 8 9}^{\star}\end{array}$ & $\begin{array}{l}5.22^{*} \\
4.11^{*} \\
6.87 \\
4.14^{\star} \\
6.21 \\
4.65^{\star} \\
6.33 \\
4.51^{\star} \\
5.13 \\
3.99^{\star}\end{array}$ \\
\hline $\begin{array}{l}\text { HO-1 control } \\
\text { HO-1 IFN- } \beta \\
\text { Old-35-si clone } 1 \text { control } \\
\text { Old-35-si clone } 1 \text { IFN- } \beta \\
\text { Old-35-si clone } 4 \text { control } \\
\text { Old-35-si clone } 4 \text { IFN- } \beta \\
\text { Old-35-si clone } 5 \text { control } \\
\text { Old-35-si clone } 5 \text { IFN- } \beta \\
\text { Control-si clone } 1 \text { control } \\
\text { Control-si clone } 1 \text { IFN- } \beta\end{array}$ & $\begin{array}{l}38.21 \\
33.2 \\
38.87 \\
37.26 \\
36.18 \\
35.99 \\
38.27 \\
38.06 \\
39.37 \\
30.23\end{array}$ & $\begin{array}{l}38.03 \\
31.95 \\
39.71 \\
37.39 \\
37.52 \\
37.4 \\
36.65 \\
38.43 \\
40.44 \\
31.79\end{array}$ & $\begin{array}{l}34.66 \\
29.82 \\
36.29 \\
30.99 \\
32.27 \\
31.1 \\
37.09 \\
33.34 \\
35.68 \\
29.73\end{array}$ & $\begin{array}{l}44.18 \\
32.04 \\
45.77 \\
44.48 \\
40.52 \\
41.06 \\
44.64 \\
45.97 \\
37.92 \\
35.85\end{array}$ & $\begin{array}{r}G_{2}+M \\
44.82 \\
33.62 \\
43.72 \\
42.28 \\
41.18 \\
40.98 \\
43.08 \\
45.56 \\
40.11 \\
40.81\end{array}$ & $\begin{array}{l}37.84 \\
29.91 \\
39.46 \\
28.21 \\
35.91 \\
29.01 \\
36.54 \\
32.36 \\
35.4 \\
27.24\end{array}$ & $\begin{array}{l}42.74 \\
35.68 \\
41.73 \\
44.43 \\
43.03 \\
46.27 \\
43.03 \\
44.74 \\
40.75 \\
37.91\end{array}$ & $\begin{array}{l}43.72 \\
39.31 \\
41.69 \\
46.11 \\
46.46 \\
45.09 \\
44.86 \\
47.96 \\
42.71 \\
37.68\end{array}$ & $\begin{array}{l}41.66 \\
33.64 \\
37.04 \\
32.13 \\
41.65 \\
32.3 \\
42.93 \\
31.58 \\
40.1 \\
35.27\end{array}$ \\
\hline $\begin{array}{l}\text { HO-1 control } \\
\text { HO-1 IFN- } \beta \\
\text { Old-35-si clone } 1 \text { control } \\
\text { Old-35-si clone } 1 \text { IFN- } \beta \\
\text { Old-35-si clone } 4 \text { control } \\
\text { Old-35-si clone } 4 \text { IFN- } \beta \\
\text { Old-35-si clone } 5 \text { control } \\
\text { Old-35-si clone } 5 \text { IFN- } \beta \\
\text { Control-si clone } 1 \text { control } \\
\text { Control-si clone } 1 \text { IFN- } \beta\end{array}$ & $\begin{array}{l}1.58 \\
1.97 \\
0.7 \\
0.67 \\
0.51 \\
0.72 \\
1.01 \\
1.13 \\
0.81 \\
0.8\end{array}$ & $\begin{array}{l}1.23 \\
1.36 \\
0.89 \\
0.73 \\
0.66 \\
0.95 \\
0.97 \\
1.11 \\
1.01 \\
1.04\end{array}$ & $\begin{array}{l}1.67 \\
1.88 \\
1.02 \\
1.19 \\
0.99 \\
0.89 \\
1.14 \\
1.24 \\
1.17 \\
1.21\end{array}$ & $\begin{array}{l}1.11 \\
6.17^{\star} \\
0.89 \\
0.92 \\
0.44 \\
1.23 \\
1.18 \\
0.98 \\
0.71 \\
4.87^{\star}\end{array}$ & $\begin{array}{l}A_{O} \\
1.02 \\
6.95^{\star} \\
1.03 \\
0.99 \\
0.81 \\
1.14 \\
1.42 \\
0.87 \\
1.14 \\
\mathbf{6 . 1 7}^{\star}\end{array}$ & $\begin{array}{l}4.21^{\star} \\
8.33^{\star} \\
3.24 \\
7.17^{\star} \\
3.49^{\star} \\
6.99^{\star} \\
3.97^{\star} \\
7.08^{\star} \\
4.38^{\star} \\
8.96^{\star}\end{array}$ & $\begin{array}{c}0.98 \\
\mathbf{1 4 . 2 1}^{\star} \\
0.66 \\
2.24 \\
0.56 \\
1.59 \\
1.24 \\
2.10 \\
0.55 \\
\mathbf{1 6 . 3 1}^{\star}\end{array}$ & $\begin{array}{c}1.12 \\
\mathbf{1 3 . 8 7 ^ { \star }} \\
0.89 \\
1.85 \\
0.97 \\
1.47 \\
1.36 \\
1.97 \\
0.87 \\
\mathbf{1 4 . 7 5}^{\star}\end{array}$ & $\begin{array}{c}6.87^{\star} \\
17.6^{\star} \\
5.84 \\
16.5^{\star} \\
4.58 \\
14.7^{\star} \\
5.11 \\
16.4^{\star} \\
6.15^{\star} \\
17.2^{\star}\end{array}$ \\
\hline
\end{tabular}

HO-1 cells, HO-1 clones expressing hPNPase old-35 siRNA (old-35-si clone 1, clone 4 and clone 5) and HO-1 clones expressing control siRNA (control-si clone 1) were either mock-transfected (control) or transfected with control siRNA or c-myc siRNA and then treated with IFN- $\beta$ (1000 U/ml) and cell cycle was analyzed by flow cytometry on day 1, 2 and 3 post-treatment. Bold data points marked with asterisks indicate significant differences $(P<0.01)$ from the control data points

monocyte/macrophage leukemia cells, IFN- $\beta$ reduces steadystate levels of Myc protein by increasing degradation through the 265 proteasome. ${ }^{24}$ In our previous studies, we revealed for the first time by employing recombinant $h P N P a s e^{\text {old-35 }}$ protein in in vitro mRNA degradation assays that a type I IFN-

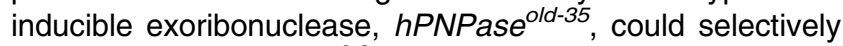
degrade c-myc mRNA. ${ }^{6,9}$ In the present studies, we now confirm that $h P N P a e^{\text {old-35 }}$ is the enzyme responsible for IFN$\beta$-mediated degradation of c-myc mRNA in human melanoma cells.

Myc is an important regulator of cell proliferation. ${ }^{25}$ Expression of exogenous Myc in cultured fibroblasts promotes S-phase entry and shortens the $G_{1}$ phase of the cell cycle, while activation of a conditional Myc is sufficient to drive quiescent cells into the cell cycle. An association between cmyc downregulation and IFN- $\alpha$-mediated $\mathrm{G}_{0} / \mathrm{G}_{1}$ arrest in Daudi cells was demonstrated, ${ }^{26}$ and it was shown that IFN- $\alpha$ induced $\mathrm{G}_{0} / \mathrm{G}_{1}$ arrest correlated with upregulation of cyclindependent kinase inhibitors (CDKI), such as p21 and p15 early in this process and p27 in the late stage of growth arrest. $^{27}$ Type I IFN treatment of Daudi cells induced p21 expression and $G_{1}$ arrest, and these events were preceded by a strong reduction in c-myc levels. ${ }^{28}$ Myc can directly suppress the transcription of p21 and p27 and promote the ubiquitination of phosphorylated p27. ${ }^{25}$ Our previous experiments confirm that overexpression of hPNPase ${ }^{\text {old-35 }}$ downregulates c-myc and upregulates p27, ${ }^{6}$ and in the present study we document that inhibition of hPNPase ${ }^{\text {old }-35}$ as 


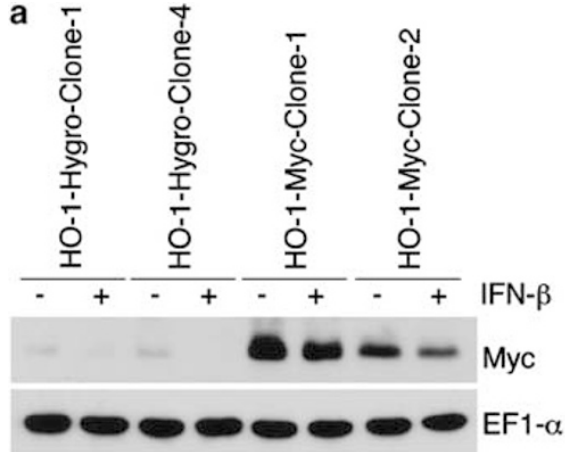

c

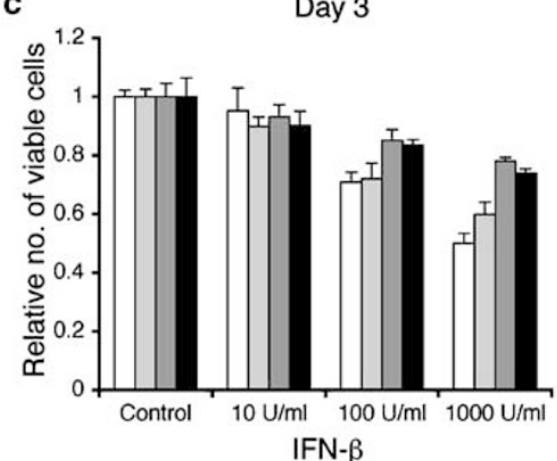

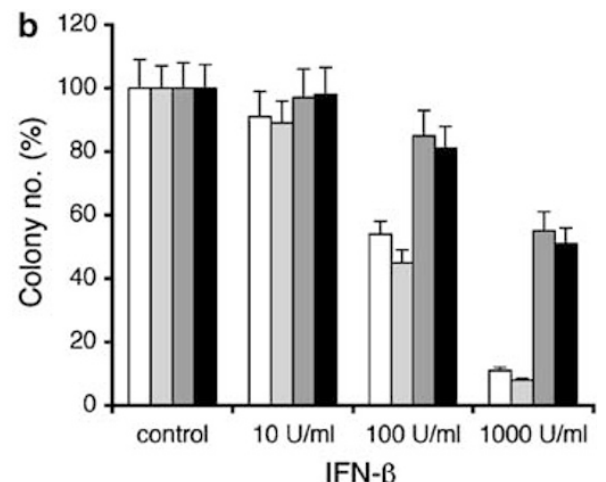

IFN- $\beta$

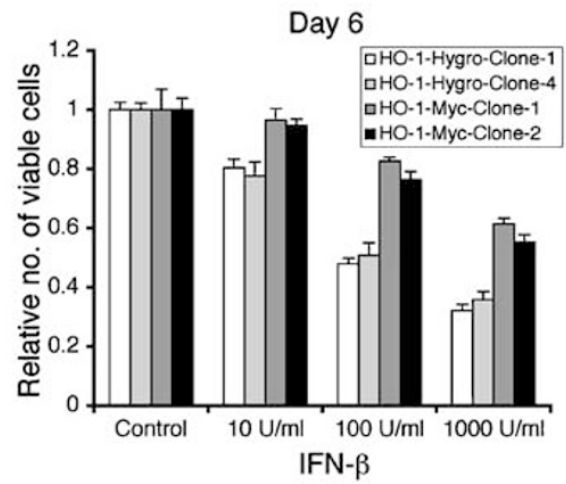

Figure 7 HO-1 clones overexpressing Myc are resistant to IFN- $\beta$-mediated growth and colony formation inhibition. (a) Myc and EF1- $\alpha$ expressions were analyzed by Western blot analysis in control HO-1 clones (HO-1-Hygro-clone-1 and HO-1-Hygro-clone-4) and Myc-overexpressing clones (HO-1-Myc-clone-1 and HO-1-Myc-clone2) treated or not with IFN- $\beta(1000 \mathrm{U} / \mathrm{ml}$ ) for 2 days. (b) Control HO-1 clones (HO-1-Hygro-clone-1 and HO-1-Hygro-clone-4) and Myc-overexpressing clones (HO-1-Mycclone-1 and HO-1-Myc-clone-2) were treated with the indicated concentrations of IFN- $\beta$ and colony formation assays were performed. Colonies were counted after 2 weeks. At least four dishes were used for each data point in each experiment. The data represent the mean \pm S.D. of two independent experiments. (c) Control HO-1 clones (HO-1-Hygro-clone-1 and HO-1-Hygro-clone-4) and Myc-overexpressing clones (HO-1-Myc-clone-1 and HO-1-Myc-clone-2) were treated with the indicated concentrations of IFN- $\beta$ and cell viability was assessed by standard MTT assay on day 3 and 6 post-treatment. The data represent the mean \pm S.D. of three independent experiments, each performed in octaplicates

Table 3 HO- 1 clones overexpressing Myc are resistant to IFN- $\beta$-induced $\mathrm{G}_{1}$ cell cycle arrest and apoptosis

\begin{tabular}{|c|c|c|c|c|c|c|}
\hline & Day 1 & Day 2 & Day 3 & Day 1 & Day 2 & Day 3 \\
\hline $\begin{array}{l}\text { HO-1-Hygro-clone- } 1 \text { control } \\
\text { HO-1-Hygro-clone- } 1 \text { IFN- } \beta \\
\text { HO-1-Hygro-clone-4 control } \\
\text { HO-1-Hygro-clone-4 IFN- } \beta \\
\text { HO-1-Myc-clone-1 control } \\
\text { HO-1-Myc-clone- } 1 \text { IFN- } \beta \\
\text { HO-1-Myc-clone-2 control } \\
\text { HO-1-Myc-clone-2 IFN- } \beta\end{array}$ & $\begin{array}{l}59.7 \\
74.84^{\star} \\
57.6 \\
69.1^{\star} \\
56.66 \\
60.2 \\
57.8 \\
61.9\end{array}$ & 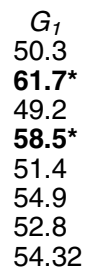 & $\begin{array}{l}50.2 \\
50.23 \\
45.8 \\
49.7 \\
49.1 \\
50.6 \\
44.6 \\
48.1\end{array}$ & $\begin{array}{c}16.3 \\
\mathbf{8 . 1}^{\star} \\
14.8^{\star} \\
7.2^{\star} \\
15.6 \\
12.5 \\
16.9 \\
13.8\end{array}$ & $\begin{array}{c}S \\
17.8 \\
7.5^{\star} \\
16.1^{\star} \\
6.1^{\star} \\
16.9 \\
11.8 \\
14.23 \\
12.5\end{array}$ & $\begin{array}{c}18.2 \\
6.3^{\star} \\
17.2 \\
5.8^{\star} \\
18.4 \\
13.6 \\
17.8 \\
12.9\end{array}$ \\
\hline $\begin{array}{l}\text { HO-1-Hygro-clone-1 control } \\
\text { HO-1-Hygro-clone-1 IFN- } \beta \\
\text { HO-1-Hygro-clone-4 control } \\
\text { HO-1-Hygro-Clone-4 IFN- } \beta \\
\text { HO-1-Myc-Clone-1 control } \\
\text { HO-1-Myc-Clone- } 1 \text { IFN- } \beta \\
\text { HO-1-Myc-clone-2 control } \\
\text { HO-1-Myc-clone-2 IFN- } \beta\end{array}$ & $\begin{array}{l}21.9 \\
14.46 \\
26.2 \\
21.8 \\
26.04 \\
25.2 \\
23.8 \\
22.4\end{array}$ & $\begin{array}{l}G_{2}+M \\
29.6 \\
22 \\
32.85 \\
28.1 \\
30.5 \\
30.1 \\
31.17 \\
30.37\end{array}$ & $\begin{array}{l}29.8 \\
28.17 \\
35.33 \\
25.7 \\
30.1 \\
28.9 \\
35.3 \\
33.6\end{array}$ & $\begin{array}{l}2.1 \\
2.6 \\
1.4 \\
1.9 \\
1.7 \\
2.1 \\
1.5 \\
1.9\end{array}$ & $\begin{array}{l}A_{O} \\
2.3 \\
8.8^{\star} \\
1.85 \\
7.3^{*} \\
1.2 \\
3.2 \\
1.8 \\
2.81\end{array}$ & $\begin{array}{c}1.8 \\
15.3^{\star} \\
1.67 \\
18.8^{\star} \\
2.4 \\
6.9 \\
2.3 \\
5.4\end{array}$ \\
\hline
\end{tabular}

Control HO-1 clones (HO-1-Hygro-clone-1 and HO-1-Hygro-clone-4) and Myc-overexpressing clones (HO-1-Myc-clone-1 and HO-1-Myc-clone-2) were treated with IFN- $\beta(1000 \mathrm{U} / \mathrm{ml})$ and cell cycle was analyzed by flow cytometry on day 1,2 and 3 post-treatment. Bold IFN- $\beta$-treated data points marked with asterisks indicate significant differences $(P<0.01)$ from the control data points

well as overexpression of c-myc protect melanoma cells from IFN- $\beta$-mediated $\mathrm{G}_{1}$ arrest. These findings firmly establish the functional and mechanistic links between

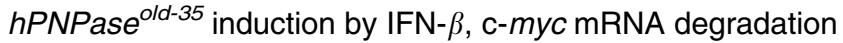
by $h P N P a s e^{\text {old }-35}$ and IFN- $\beta$-induced cell cycle arrest and eventual apoptosis (Figure 8). 


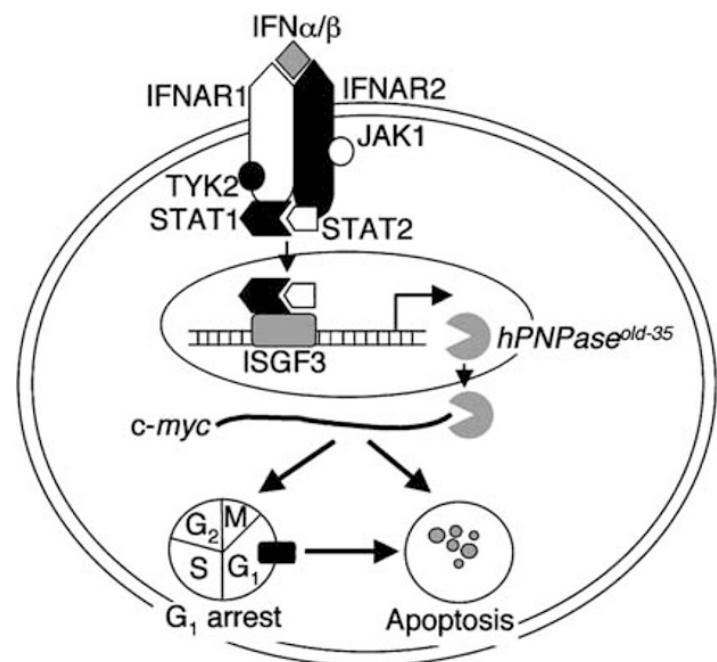

Figure 8 A schematic model of regulation of $h P N P a s e^{\text {old }-35}$ and c-myc by IFN$\beta$. Binding of IFN- $\alpha / \beta$ to the cognate receptors IFNAR1 and IFNAR2 result in cross-phosphorylation and activation of TYK2 and JAK1, with subsequent phosphorylation of STAT1 and STAT2. Phosphorylated STAT1/STAT2 heterodimer translocates to the nucleus, associates with p48 to form the ISGF3 complex that binds to the promoter of hPNPase $e^{\text {old }-35}$ and upregulates its transcription. $h P N P a e^{\text {old }-35}$ protein enters into the cytoplasm and binds and degrades c-myc mRNA by its $3^{\prime}, 5^{\prime}$ exoribonuclease activity. Downregulation of cmyc results in cell cycle arrest in $\mathrm{G}_{1}$ phase, with subsequent apoptosis

What is the practical significance of our observations? Myc is overexpressed in multiple tumor subtypes, including melanomas. ${ }^{25}$ The expression level of Myc inversely correlates with patient survival and thus may be used as a prognostic marker in different melanomas. ${ }^{29-32}$ Indeed, antisense inhibition of c-myc significantly inhibited the growth of melanoma cells in in vitro cultures ${ }^{33}$ and improved the response to chemotherapy in human melanoma xenografts in nude mice. ${ }^{34}$ Type I IFNs have been used as adjuvant therapy for malignant melanoma with significant but limited success and high toxicity. ${ }^{35}$ Experimental overexpression of Myc in mouse fibroblasts and myeloblastic cells renders these cells resistant to cell cycle arrest by type I IFNs. ${ }^{36,37}$ Uveal melanomas with high c-myc expression are also associated with IFN- $\alpha$ resistance. ${ }^{38}$ In these contexts and based on the poor survival of patients with malignant melanoma, improved therapies are mandated and cancer-cell-specific expression of $h P N P a s e^{\text {old }-35}$, by means of the telomerase or progression elevated gene-3 promoter, ${ }^{39,40}$ might prove beneficial as an innovative adjuvant therapeutic approach that exploits the ability of $h P N P a s e^{\text {old-35 }}$ to degrade c-myc mRNA, thus inducing target cancer cell-specific growth arrest culminating in apoptosis.

\section{Materials and Methods}

\section{Cell lines and cell viability assays}

FM516-SV (referred to as FM516) normal immortal human melanocyte, WM35 early radial growth phase (RGP) primary human melanomas, $\mathrm{HO}-1$ and MeWo metastatic melanomas, 2fTGH human fibrosarcoma and its derivates U1A, U3A, U4A and U5A, HeLa human cervical carcinoma and 293 adenovirus transformed human embryonic kidney (HEK 293) cells were cultured in Dulbecco's modified Eagle's medium containing $10 \%$ fetal bovine serum and penicillin $(100 \mathrm{U} / \mathrm{ml})$ and streptomycin $(100 \mu \mathrm{g} / \mathrm{ml})$. 2fTGH cells are wild type in IFN signaling, while its derivates U1A, U3A, U4A and U5A have defects in IFN signaling that could be complemented by expression of TYK2, STAT1, JAK1 or IFNAR2, respectively. ${ }^{13}$ Cell growth and viable cell numbers were monitored by 3-(4,5-dimethylthiazol2-yl)-2,5-diphenyl tetrazolium bromide (MTT) staining as described. ${ }^{6}$

\section{Generation of lentivirus expressing siRNA for hPNPase old $-35^{-3}$}

Using the software siRNA Target Finder (Ambion, Austin, TX, USA), four potential siRNAs for hPNPase ${ }^{\text {old-35 }}$ were designed and the siRNAs were constructed by in vitro transcription using the Silencer siRNA construction kit (Ambion) according to the manufacturer's protocol. These siRNAs were transfected into HeLa cells using Lipofectamine 2000 (Invitrogen, Carlsbad, CA) according to the manufacturer's protocol and the next day the cells were treated with $1000 \mathrm{U} / \mathrm{ml}$ IFN- $\beta$ for $24 \mathrm{~h}$. The expression of $h P N P a s e^{\text {old }-35}$ in the lysates of these cells was analyzed by Western blot analysis. The siRNA demonstrating the maximum inhibition of $h P N P a-$ se $^{\text {old-35 }}$ induction by IFN- $\beta$ was selected for construction of the lentivirus. The hPNPase $e^{\text {old-35 }}$ and control siRNA sequences were $5^{\prime}-\mathrm{AA}$ CAAAACCTTCCCCTTCCCA-3' and 5'-AAGGGTCGTCTATAGGGATC GAT-3', respectively. Lentiviruses expressing either control siRNA or

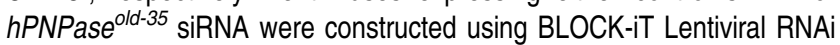
Expression System (Invitrogen) according to the manufacturer's protocol. The siRNA was first ligated into BLOCK-iT U6 RNAi Entry Vector that drives expression of the siRNA under control of the human U6 promoter. The siRNA expression cassette was transferred to pLenti6 BLOCK-iTDEST lentiviral vector by the LR recombination reaction. The resultant construct was transfected into HEK293FT cells with Lipofectamine 2000 along with ViraPower lentiviral packaging mix that expresses the proteins required for lentivirus replication. The lentivirus was amplified and titered by standard plaque assay.

\section{Generation of stable cell clones}

Stable clones of HO-1 cells expressing either control siRNA or hPNPase ${ }^{\text {old-35 }}$ siRNA were generated by transducing the cells with lentiviruses expressing the corresponding siRNA and selecting clones for 2 weeks using $4 \mu \mathrm{g} / \mathrm{ml}$ blasticidin. Stable $\mathrm{HO}-1$ clones expressing c-myc were generated by transfecting $\mathrm{HO}-1$ cells with a c-myc expression vector and selecting the cells for 2 weeks with $100 \mu \mathrm{g} / \mathrm{ml}$ hygromycin. Transfecting the cells with empty vector and selecting with hygromycin generated the corresponding control clones.

\section{Cell cycle analysis}

Cells were harvested, washed in PBS and fixed overnight at $-20^{\circ} \mathrm{C}$ in $70 \%$ ethanol. The cells were treated with RNase $A(1 \mathrm{mg} / \mathrm{ml})$ at $37^{\circ} \mathrm{C}$ for $30 \mathrm{~min}$ and then with propidium iodide $(50 \mu \mathrm{g} / \mathrm{ml})$. Cell cycle was analyzed using a FACScan flow cytometer and data were analyzed using CellQuest software (Becton Dickinson, San Jose, CA, USA).

\section{Colony formation assays}

In total, 1000 cells were plated in 6-cm dishes and then treated with different doses of IFN- $\beta$ for 2 weeks, at which point the colonies were fixed, stained with Giemsa and colonies $\geqslant 50$ cells were counted. 


\section{Transfection of SiRNA}

Cells $5 \times 10^{5}$ were plated in a $6 \mathrm{~cm}$ dish and the next day were transfected with $25 \mathrm{nM}$ of either control siRNA or c-myc siRNA (Ambion; catalogue\# 4250) using Lipofectamine 2000 (Invitrogen) according to the manufacturer's protocol. After $24 \mathrm{~h}$, the cells were trypsinized and seeded into 96 well plates for cell viability assays and $6-\mathrm{cm}$ dishes for colony formation assays and cell cycle analyses as described above.

\section{RNA isolation and Northern blot analysis}

Total RNA was extracted from cells using Qiagen RNeasy mini kit (Qiagen) according to the manufacturer's protocol and Northern blotting was performed as described. ${ }^{6}$ The cDNA probes used were a 400-bp fragment from human c-myc, a 500-bp fragment from hPNPase ${ }^{\text {old-35 }}$ and full-length human GAPDH. For analysis of the half-life of c-myc mRNA, cells were either untreated or treated with IFN- $\beta(1000 \mathrm{U} / \mathrm{ml})$ for $24 \mathrm{~h}$ and then treated with Act-D $(5 \mu \mathrm{g} / \mathrm{ml})$ for $0.5,1,2,4$ and $8 \mathrm{~h}$, following which the cells were harvested for total RNA extraction and Northern blot analysis.

\section{Western blot analysis}

Western blotting was performed as described previously. ${ }^{6}$ Briefly, cells were harvested in RIPA buffer containing protease inhibitor cocktail (Roche, Mannheim, Germany), $1 \mathrm{mM} \mathrm{Na}_{3} \mathrm{VO}_{4}$ and $50 \mathrm{mM} \mathrm{NaF}$ and centrifuged at 12000 r.p.m. for $10 \mathrm{~min}$ at $4^{\circ} \mathrm{C}$. The supernatant was used as total cell lysate. In all, $30 \mu \mathrm{g}$ of total cell lysate was used for SDS-PAGE and transferred to a nitrocellulose membrane. The primary antibodies included: Myc (1:200; mouse monoclonal; Santa Cruz biotechnology, Santa Cruz, CA, USA), hPNPase ${ }^{\text {old- } 35}$ (1: 10000; chicken polyclonal), MDA-5 (1:5000; rabbit polyclonal) and EF1 $\alpha$ (1:1000; mouse monoclonal; Upstate Biotechnology, Waltham, MA, USA).

\section{Statistical analysis}

Statistical analysis was performed using one-way analysis of variance (ANOVA), followed by Fisher's protected least significant difference analysis.

\section{Acknowledgements}

The present study was supported in part by National Insitutes of Health grant CA097318, the Samuel Waxman Cancer Research Foundation and the Chernow Endowment. PBF is the Michael and Stella Chernow Urological Cancer Research Scientist and a SWCRF Investigator.

\section{References}

1. Stark GR, Kerr IM, Williams BR, Silverman RH and Schreiber RD (1998) How cells respond to interferons. Annu. Rev. Biochem. 67: 227-264

2. Pestka S (1997) The interferon receptors. Semin. Oncol. 24: S9-18-S9-40

3. Leszczyniecka M, Kang DC, Sarkar D, Su ZZ, Holmes M, Valerie K and Fisher PB (2002) Identification and cloning of human polynucleotide phosphorylase, hPNPase $e^{\text {old }-35}$, in the context of terminal differentiation and cellular senescence. Proc. Natl. Acad. Sci. USA 99: 16636-16641

4. Leszczyniecka M, Su ZZ, Kang DC, Sarkar D and Fisher PB (2003) Expression regulation and genomic organization of human polynucleotide phosphorylase, hPNPase ${ }^{\text {old }-35}$, a type I interferon inducible early response gene. Gene 316 : 143-156
5. Leszczyniecka M, DeSalle R, Kang DC and Fisher PB (2003) The origin of polynucleotide phosphorylase domains. Mol. Phylogenet. Evol. 31: 123-130

6. Sarkar D, Leszczyniecka M, Kang DC, Lebedeva IV, Valerie K, Dhar S, Pandita TK and Fisher PB (2003) Down-regulation of Myc as a potential target for growth arrest induced by human polynucleotide phosphorylase ( $h P N P a e^{\text {old-35 }}{ }^{\text {) }}$ in human melanoma cells. J. Biol. Chem. 278: 24542-24551

7. Jiang $\mathrm{H}$, Lin J and Fisher PB (1994) A molecular definition of terminal cell differentiation in human melanoma cells. Mol. Cell Differ. 2: 221-239

8. Campisi J (1996) Replicative senescence: an old lives' tale? Cell 84: $497-4500$

9. Sarkar D, Park ES, Emdad L, Randolph A, Valerie K and Fisher PB (2005) Defining the domains of human polynucleotide phosphorylase (hPNPase ${ }^{\text {old }-35}$ ) mediating cellular senescence. Mol. Cell. Biol. 25: 7333-7343

10. Sarkar D, Lebedeva IV, Emdad L, Kang DC, Baldwin Jr. AS and Fisher PB (2004) Human polynucleotide phosphorylase (hPNPase ${ }^{\text {old-35 }}$ ): a potential link between aging and inflammation. Cancer Res. 64: 7473-7478

11. Jonak GJ, Knight Jr. E and Jr (1984) Selective reduction of c-myc mRNA in Daudi cells by human beta interferon. Proc. Natl. Acad. Sci. USA 81: 17471750

12. Dani C, Mechti N, Piechaczyk M, Lebleu B, Jeanteur P and Blanchard JM (1985) Increased rate of degradation of c-myc mRNA in interferon-treated Daudi cells. Proc. Natl. Acad. Sci. USA 82: 4896-4899

13. Pellegrini S, John J, Shearer M, Kerr IM and Stark GR (1989) Use of a selectable marker regulated by alpha interferon to obtain mutations in the signaling pathway. Mol. Cell. Biol. 9: 4605-4612

14. de Veer MJ, Holko M, Frevel M, Walker E, Der S, Paranjape JM, Silverman RH and Williams BR (2001) Functional classification of interferon-stimulated genes identified using microarrays. J. Leukoc. Biol. 69: 912-920

15. Meurs $E$ and Hovanessian AG (1988) Alpha-interferon inhibits the expression of heavy chain mu messenger RNA in Daudi cells. EMBO J. 7: 1689-1696

16. So EY, Park HH and Lee CE (2000) IFN-gamma and IFN-alpha posttranscriptionally down-regulate the IL-4-induced IL-4 receptor gene expression. J. Immunol. 165: 5472-5479

17. Chatterjee D and Savarese TM (1992) Posttranscriptional regulation of c-myc proto-oncogene expression and growth inhibition by recombinant human interferon-beta ser17 in a human colon carcinoma cell line. Cancer Chemother. Pharmacol. 30: 12-20

18. Resnitzky D, Yarden A, Zipori D and Kimchi A (1986) Autocrine beta-related interferon controls c-myc suppression and growth arrest during hematopoietic cell differentiation. Cell 46: 31-40

19. Jiang H, Lin J, Young SM, Goldstein NI, Waxman S, Davila V, Chellappan SP and Fisher PB (1995) Cell cycle gene expression and E2F transcription factor complexes in human melanoma cells induced to terminally differentiate. Oncogene 11: 1179-1189

20. Kelly JM, Gilbert CS, Stark GR and Kerr IM (1985) Differential regulation of interferon-induced mRNAs and c-myc mRNA by alpha- and gammainterferons. Eur. J. Biochem. 153: 367-371

21. Harel-Bellan A, Brini AT and Farrar WL (1988) IFN-gamma inhibits c-myc gene expression by impairing the splicing process in a colony-stimulating factor dependent murine myeloid cell line. J. Immunol. 141: 1012-1017

22. Ramana CV, Grammatikakis N, Chernov M, Nguyen H, Goh KC, Williams BR and Stark GR (2000) Regulation of c-myc expression by IFN-gamma through Stat1-dependent and -independent pathways. EMBO J. 19: 263-272

23. Raveh T, Hovanessian AG, Meurs EF, Sonenberg N and Kimchi A (1996) Double-stranded RNA-dependent protein kinase mediates c-Myc suppression induced by type I interferons. J. Biol. Chem. 271: 25479-25484

24. Hu X, Bies $J$ and Wolff $L$ (2005) Interferon beta increases c-Myc proteolysis in mouse monocyte/macrophage leukemia cells. Leuk. Res. 29: 1307-1314

25. Grandori C, Cowley SM, James LP and Eisenman RN (2000) The Myc/Max/ Mad network and the transcriptional control of cell behavior. Annu. Rev. Cell Dev. Biol. 16: 653-699

26. Einat M, Resnitzky D and Kimchi A (1985) Close link between reduction of c-myc expression by interferon and G0/G1 arrest. Nature 313: 597-600

27. Sangfelt $O$, Erickson $S$, Castro J, Heiden T, Gustafsson A, Einhorn $S$ and Grander D (1999) Molecular mechanisms underlying interferon-alpha-induced G0/G1 arrest: CKI-mediated regulation of G1 Cdk-complexes and activation of pocket proteins. Oncogene 18: 2798-2810

28. Subramaniam PS, Cruz PE, Hobeika AC and Johnson HM (1998) Type I interferon induction of the Cdk-inhibitor p21WAF1 is accompanied by ordered 
G1 arrest, differentiation and apoptosis of the Daudi B-cell line. Oncogene 16: $1885-1890$

29. Ross DA and Wilson GD (1998) Expression of c-myc oncoprotein represents a new prognostic marker in cutaneous melanoma. Br. J. Surg. 85: 46-51

30. Grover R, Grobbelaar AO, Hudson DA, Forder M, Wilson GD and Sanders R (1997) The clinical significance of oncogene expression in subungual melanoma. Br. J. Plast. Surg. 50: 15-19

31. Grover R, Ross DA, Wilson GD and Sanders R (1997) Measurement of c-myc oncoprotein provides an independent prognostic marker for regional metastatic melanoma. Br. J. Plast. Surg. 50: 478-482

32. Chana JS, Grover R, Wilson GD, Hudson DA, Forders M, Sanders R and Grobbelaar AO (2001) The prognostic importance of c-myc oncogene expression in head and neck melanoma. Ann. Plast. Surg. 47: 172-177

33. Chana JS, Grover R, Tulley P, Lohrer H, Sanders R, Grobbelaar AO and Wilson GD (2002) The c-myc oncogene: use of a biological prognostic marker as a potential target for gene therapy in melanoma. Br. J. Plast. Surg. 55: 623-627

34. Zupi G, Scarsella M, Semple SC, Mottolese M, Natali PG and Leonetti C (2005) Antitumor efficacy of bcl-2 and c-myc antisense oligonucleotides in combination with cisplatin in human melanoma xenografts: relevance of the administration sequence. Clin. Cancer Res. 11: 1990-1998

35. McClay EF (2002) Adjuvant therapy for patients with high-risk malignant melanoma. Semin. Oncol. 29: 389-399

36. Einat M and Kimchi A (1988) Transfection of fibroblasts with activated c-myc confers resistance to antigrowth effects of interferon. Oncogene 2: 485-491

37. Resnitzky D and Kimchi A (1991) Deregulated c-myc expression abrogates the interferon- and interleukin 6-mediated G0/G1 cell cycle arrest but not other inhibitory responses in M1 myeloblastic cells. Cell. Growth Differ. 2: 33-41

38. Tulley PN, Neale M, Jackson D, Chana JS, Grover R, Cree I, Grobbelaar AO and Wilson GD (2004) The relation between c-myc expression and interferon sensitivity in uveal melanoma. Br. J. Ophthalmol. 88: 1563-1567

39. Gu J and Fang B (2003) Telomerase promoter-driven cancer gene therapy. Cancer Biol. Ther. 2: S64-70

40. Su ZZ, Sarkar D, Emdad L, Duigou GJ, Young CS, Ware J, Randolph A, Valerie $\mathrm{K}$ and Fisher PB (2005) Targeting gene expression selectively in cancer cells by using the progression-elevated gene-3 promoter. Proc. Natl. Acad. Sci. USA 102: $1059-1064$ 